Article

\title{
Development of a Building Information Modeling-Parametric Workflow Based Renovation Strategy for an Exemplary Apartment Building in Seoul, Korea
}

\author{
Fabrizio Maria Amoruso ${ }^{1}$, Udo Dietrich ${ }^{2}$ and Thorsten Schuetze ${ }^{3, *(1)}$ \\ 1 Department of Architecture, HafenCity University, Ueberseeallee 16, 20457 Hamburg, Germany; \\ fabrizio.m.amoruso@gmail.com \\ 2 Department of Building Physics, HafenCity University, Ueberseeallee 16, 20457 Hamburg, Germany; \\ udo.dietrich@hcu-hamburg.de \\ 3 Department of Architecture, College of Engineering, SungKyunKwan University, 2066 Seobu-ru Jangan-gu, \\ Suwon-si Gyeonggi-do 440-746, Korea \\ * Correspondence: t.schuetze@skku.edu; Tel.: +82-31-299-4763; Fax: +82-31-290-7570
}

Received: 17 October 2018; Accepted: 25 November 2018; Published: 29 November 2018

check for updates

\begin{abstract}
Apartments in South Korea have high maintenance costs and an average lifetime of 25 years due to poor construction qualities. The common apartment redevelopment strategy is completely demolishing the neighborhoods and then replacing them with new buildings. However, this research discusses the framework for the refurbishment of an existing building in Seoul using Building Information Modeling (BIM) and parametric tools. The virtual model of an exemplary existing building is constructed in a BIM environment. Parametric software is used to simulate the building's environmental performance, in order to determine its energy demand for heating and cooling and the indoor comfort. In order to reduce the energy demand for heating and cooling, improve the indoor comfort, generate photovoltaic energy and extend the building's lifetime, a modular building envelope renovation system is developed. Building simulation results of the improved building envelope are used to quantify the differences with the existing building. The research results illustrate significant improvements in energy performance, comfort and lifetime extension that can be achieved. Furthermore, a guideline for a streamlined building optimization process is provided, that can be transferred and used for the planning and optimization of other building renovation projects.
\end{abstract}

Keywords: apartment units; Building Information Modeling (BIM); parametric optimization software; environmental assessment; comfort analysis; energy simulations; modular construction

\section{Introduction}

In 2010, $47 \%$ of the South Korean population lived in apartments that were constructed as early as in 1960 [1]. Approximately 8 Million buildings, containing more than $60 \%$ of all housing units, are apartments [2]. Apartments have become an important element of the Korean housing development and economy starting from the National Housing Act of 1972, an ambitious plan for the construction of 2.5 Million housing units [3]. The implementation of National Housing Act of 1972 and the construction of an immense amount of apartment buildings in a short time had significant influence on construction practices and the development of cost optimized building methods.

The growing and competitive real estate market in the 1980s resulted to the construction of low-quality apartments. The reasons were mainly to minimize the building costs and maximize the profits [4]. Construction materials were of comparably low quality and the building envelope had 
minimal thermal insulation. Also, the heating and cooling systems were simple and barely meeting the requirements for a comfortable indoor climate during cold winter and hot summer months [5]. The poor quality of the building in general resulted in a comparably fast aging and high maintenance demand within a short period. Therefore the lifetime of apartments from this period is, in average, approximately 20 years [6].

By the end of the 1980s, 23\% of the urban population was still living in poor housing conditions [7]. To meet the persistent need for affordable low-cost housing, the Korean government launched a plan for the new construction of additional two million housing units in 1988 [8]. As the available free urban space for the construction of new housing areas were limited, the land value of existing old apartment districts and substandard settlements increased [4]. The rent gap [9] between the actual and potential higher land value would attract the interest of speculators [10].

In 1984, the program for Joint Redevelopment Projects (JRP) [11] was introduced. JRP consisted of a cooperation initiative between real estate developers and dwellers, of both formal and informal degraded neighborhoods. JRP aimed for the conjunct planning and construction of new apartment districts in existing built up areas after the completion of their demolition. JRP projects concerned all urban area and aged apartment complexes [12]. The construction of new JRP apartment districts was associated with an increase of the previous Floor-to-Area Ratio (FAR) by approximately $100 \%$. The number of stories were increased from a maximum of 15 in the early 1990s, to tower type apartments with 40-50 levels in the 2000s [13].

As at 2012, almost $42 \%$ of the apartment buildings had reached an average lifetime of 20 years [2]. The significant increase of maintenance costs of old apartment buildings [14] motivated residents to find alternative solutions to the poor living conditions. Alternatives were relocation to other districts or consideration of redevelopment initiatives [15]. Building companies had interest in maximizing profit generation by new constructions, increase of urban density and selling of new apartments. Therefore old apartment complexes were increasingly targeted to be included in JRP programs, with the aim of completely demolishing them and replacing with new residential buildings [16]. JRP initiatives continued to be the most common strategy for the remodeling of Korean residential neighborhoods. In 2002, approximately 11,288 km² of urban land only in Seoul were object of JRP projects and 125 new JRP projects with an overall area of $6070 \mathrm{~km}^{2}$ were planned [17]. By 2008, 124,000 buildings were demolished in the framework of JRP projects [18].

In 2008, a national plan, the so-called Green Growth $[19,20]$ initiative, was announced. Included were the Framework Act on Law Carbon Green Growth [21] and the introduction of the Green Economy [22]. Main objectives were to reduce greenhouse gasses (GHG) emissions, [23] increase the market for renewable production technologies and the reduction of industrial and urban pollution [24]. For the building and construction sector, a roadmap for the reduction of $\mathrm{CO}_{2}$ emissions in the period from 2015 and 2025 was defined [25]. The Housing Act was reformed and stronger requirements for increased thermal insulation of building envelopes and reduction of service energy consumption of new residential buildings were introduced. The Act included the gradual reduction of permitted building envelope U-values in the designated period as well as the production of renewable energy [26]. By 2025 all new residential building constructed should have nearly net zero energy demand for heating and cooling and the energy demand of new non-residential construction should be reduced by $60 \%$ [27]. In the period 2000 to 2010 an average of 3800 new apartment buildings were constructed yearly in South Korea (Figure 1). 


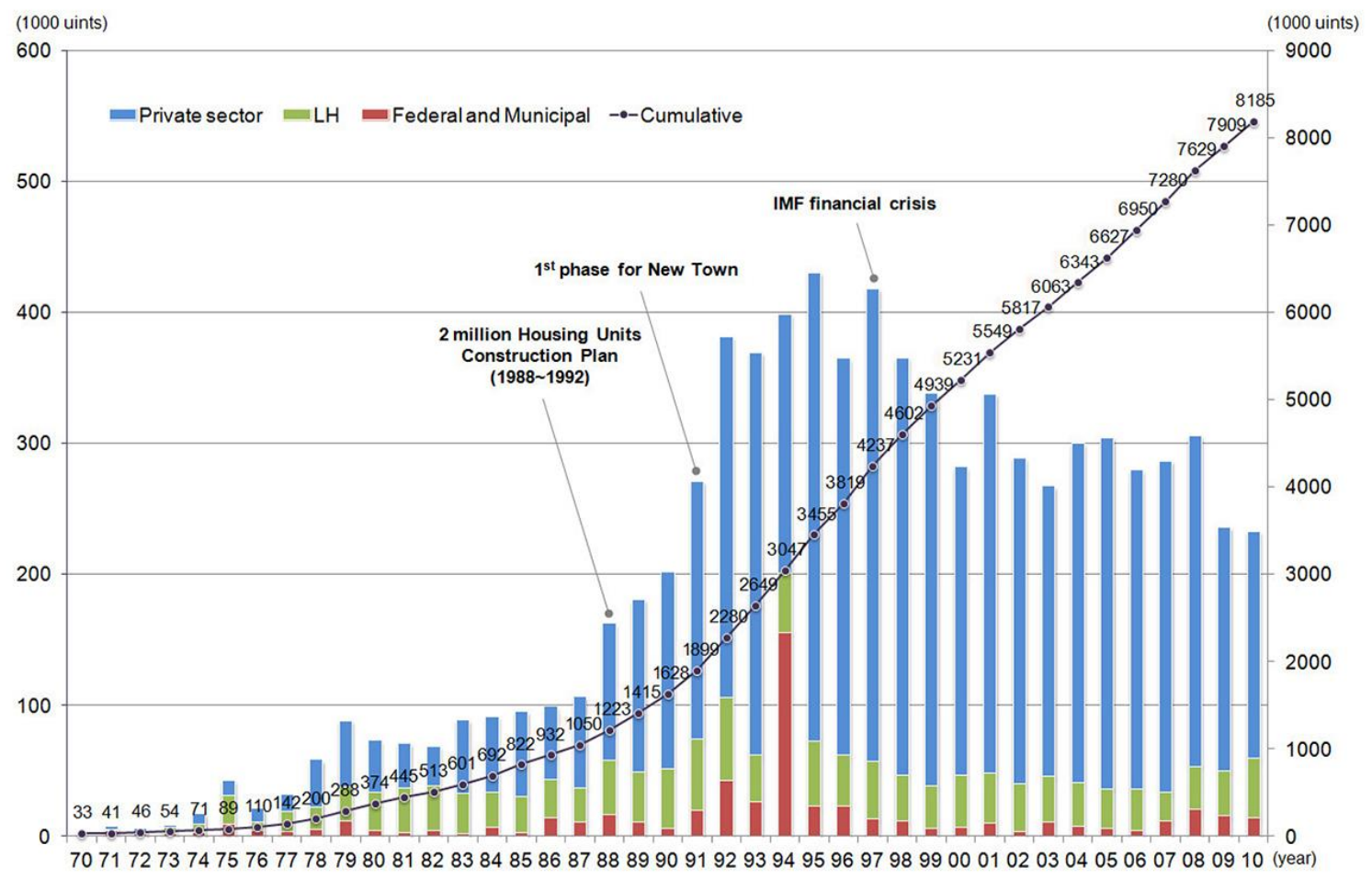

Figure 1. Housing supply in the South Korea in the period between 1970 and 2010. LH is the acronym for Land \& Housing Corporation a public company tasked with sustainable and innovative housing projects [2].

In accordance with the Green Growth plan, building regulations and interests in maintaining profitable businesses, the real estate sector had continued with the demolishment of existing neighbourhoods and construction of new apartment complexes in contrast to the renovations of existing buildings [28]. Construction companies still succeeded to convince house owners to demolish their homes and build new apartments even though the supply of housing had already met the demand on national level to almost $100 \%$ [29]. However, due to regional interest, an ongoing demand and construction of houses was concentrated in Seoul bigger metropolitan area, where the so-called green urban development projects were also associated with the destruction of natural green areas [30,31]. Apartments that were 20 years or older were classified as residential buildings with the highest redevelopment value [32]. The demolition of existing apartment complexes was associated with an enormous production of demolition waste [33] and immense demand for new building materials and $\mathrm{CO}_{2}$ emissions for new building constructions [34]. Social displacement and gentrification processes occurred after redevelopments as a result of increased real estate values for the new so-called green and smart new housing estates [35,36]. In contrast to such new development projects, the renovation of existing apartments would be associated with lower profits for building companies, but also with less resource consumption and smaller environmental impacts. Energy consumption and $\mathrm{CO}_{2}$ emissions would be reduced and the lifetime of apartment buildings extended. Social displacement and gentrification processes would be avoided. Housing owners could stay in their apartments and participate in the planning and design for a sustainable renovation of their apartments. The main challenge was the quantification of monetary costs and achievable reductions of $\mathrm{CO}_{2}$ emissions and energy consumption associated with the renovation of buildings [37]. The associated monetary costs, as well as the results and impacts of a potential building renovation were the main influencing factors in the decision making pro or con the renovation of an existing building, of construction companies and residents alike [38,39].

Recent studies have focused on calculating the average energy demand of Korean apartment buildings depending on specific properties such as cubature, orientation and size $[40,41]$. 
The calculation involves statistical data on the average primary energy consumption of building constructed before and after [42] the introduction the new energy saving norms. The results found that approximately $60-65 \%$ [43] of the energy consumed for the operation of apartments is spent in heating and cooling of indoors [44]. Accordingly, specific factors influencing the heating and cooling demand have been investigated and solutions for the reduction of energy consumption have been proposed, such as the improvement of the Korean floor heating system (Korean: Ondol) $[45,46]$ and thermal insulation of the building envelope $[47,48]$.

Recent research has concentrated on applying software tools and energy simulation methods to calculate the energy demand of apartment buildings according to specific renovation measures, such as the reduction of building envelope U-values [49]. Results indicate an achievable average reduction of heating and cooling energy demands of approximately $40 \%$ of apartments with improved building envelopes in comparison to the existing apartments [50,51]. In order to improve the planning of apartment renovation processes, studies on the application of Building Information Modeling (BIM) software have been conducted [52]. The application of BIM software in the planning of renovation projects facilitates the definition and comparison of different renovation options based on quantitative criteria and efficiency of planning of specific renovation measures [53]. However, no systematic Korean apartment renovation strategy framework is available yet.

Therefore, this research focuses on the development of an apartment building renovation strategy based on BIM and parametric environmental analysis software. The aim is to develop a parametric framework for the definition of improvement strategies based on multiple optimization measures, such as the reduction of transmission heat losses by improved thermal insulation of the building envelope and renewable energy production with Building Integrated Photovoltaics (BIPV). The basis of this research is the identification of an exemplary apartment building in Seoul and the digital reconstruction of the existing building with BIM software. The model includes the complete building with specific properties of materials, layers and components. Information from the BIM model is imported into specific parametric software tools, that facilitate the simulations of the apartment's energy consumption for heating and cooling. Furthermore, the indoor comfort is calculated based on the definition of specific criteria and data defining the local basic conditions over the period of one year. The renovation strategy includes the development of an optimized modular building envelope system to replace the existing building envelope and to be mounted on the existing building construction. The results of the building simulations are used for the definition and optimization of the specific new building envelope modules' properties. The new envelope system is included in the BIM model of the optimized building in order to provide a complete overview of the renovated building project.

\section{Tools and Methods}

This research was based on the virtual reconstruction of an existing exemplary Korean apartment building with BIM software and the analysis of energy consumption and comfort condition of occupants.

For the construction of a virtual model of the existing apartment building, the BIM software Autodesk Revit 2018 (Autodesk, San Rafael, CA, USA) was used [54]. Revit facilitated the definition of materials and their location within the three dimensional model. Building components and specific layers with related physical properties were defined and assembled, for example, in external walls, roofs, walls and slabs constructions. The specific components were used for the composition of the virtual building model. The composition of specific components such as windows, doors, façade and roof components and structural elements, have been defined individually. The defined components were multiplied, modified and used throughout the building model. The components can be also exported to other models and be used in other projects. The defined building materials' and components' data, as well as the layout of internal spaces were exported from Revit and imported in the Computer Aided Design (CAD) software Rhinoceros SR5 (Robert McNeel \& Associates, Seattle, WA, USA) and its parametric module Grasshopper 0.9 [55]. The building geometry has 
been exported from Revit to Rhinoceros in DWG (Drawing) ACIS solid format and imported in the parametric tools as referenced geometries. Construction data from the Revit families have been exported to Microsoft Excel 2017 [56] spreadsheets and imported in the parametric tool through the component Bumblebee [57]. The finalized parametric component construction defined in Grasshopper has been re-imported in Revit with the DWG ACIS solid format for the definition of distinct building envelope component families. The environmental analysis of the virtual apartment building was executed with the parametric tools Ladybug and Honeybee for Grasshopper [58]. Ladybug and Honeybee were used to execute a range of parametric environmental building analyses such a calculations of solar radiation, wind speed and wind intensity. The two tools were also used to create maps of outdoor comfort. Furthermore, Honeybee was used for the provision of a variety of components for specific energy and lighting related analyses, by interfacing the parametric module Grasshopper with external free environmental simulation software. The program WINDOW 7.6 [59] was used to calculate thermal and optical properties of the window systems. The software THERM 7.5 (Lawrence Berkeley National Laboratory, Berkeley, CA, USA) [60] facilitated the simulation of the thermal gradient through two-dimensional building sections that were constructed in Rhinoceros and physical properties of material layers parametrically that were defined with Honeybee. The software Radiance 5.2 (Booksurge LLC, Charleston, SC, USA) [61] facilitated the simulation of lighting in indoor and outdoor spaces depending on the definition of materials' specific optical properties. The software Energyplus 9.0.1 (Department of Energy's (DOE) Building Technologies Office, Washington, DC, USA) [62] was used to calculate the U-values of building components from the physical properties of the different materials. Based on the defined characteristics of the building's construction components, Energyplus was used to execute a zone-based energy simulation of the analysed reference apartment in order to calculate the energy demand for heating and cooling. Results concerning energy demand and indoor temperature have been re-imported in Ladybug, which was used for the calculation of the comfort condition for occupants according to the adaptive comfort [63] predictive model.

The basic method of the building analysis and simulation framework was based on the following content and order:

1. Virtual building reconstruction using BIM: Virtual reconstruction of the existing apartment building and the surrounding basic conditions using the BIM software Revit. The building consisted of the horizontal and vertical repetition of a single apartment unit.

2. Climate and solar radiation analysis of the building site: The analysis of the sun path for the climate zone of Seoul and calculation of incident solar radiation on the envelope of building 103 were executed by subdividing the building envelope in sensor areas of maximum $1 \times 1 \mathrm{~m}$.

3. Building envelope analysis: Calculation of U-values for single material layers and opaque constructions with Energyplus; calculation of glazing g-values and cumulative U-values for window frames and glass panels with WINDOW.

4. Energy analysis: Using the parametric interface for the software Energyplus, a zone-based energy analysis of a reference apartment unit in the building was conducted to provide an assessment of the energy demand for heating and cooling. Internal and external heat gains and losses due to infiltration and ventilation based on the existing building conditions were included in the analysis. Occupation, ventilation, heating and cooling set points schedules for the apartment were defined based on apartment users' behaviour and occupation modeling.

5. Thermal comfort analysis: Calculation of the indoor comfort conditions were executed according to the adaptive comfort model (EN 15251 comfort class II [64]) on the basis of temperature results from the Energyplus simulation and climate data for Seoul. The Energyplus simulation results included zoned air and mean radiant temperatures, as well as relative humidity. The adaptive model was adjusted in order to take into account technical heating and cooling, and natural ventilation in the thermal balance of the apartment. For the adjustment of the adaptive model a hybrid evaluation method was defined, with a ratio of $0.3 / 0.7$ between technical heating and 
cooling and natural ventilation. The use of mixed adaptive comfort models [63] is currently not specified in the adaptive comfort standards (ASHRAE 552007 and EN 15251 2007). However, different studies have approached the problem of including both active and passive means of heating and cooling in building simulation modeling. Accordingly, hybrid adaptive comfort models have been recently proposed $[65,66]$. The parametric tool Ladybug automatically adjusted comfort thresholds in relation to the introduction of active heating and cooling systems in the adaptive model. The defined ratio represented the respective influence in terms of internal temperature change between passive and active means of heating and cooling, accounting for the use of variable heating and cooling set points and defining a non-linear indoor comfortable temperature range that varied depending on the outside temperatures. To evaluate the level of comfort for apartment indoors, a constant metabolic rate of 1.2 met and different levels for occupants 'clothing, ranging from 0.45 (light t-shirt and short pants for summer) to 1 (three-pieces suit for winter), were determined by hourly temperatures. The time threshold for the annual comfort analysis was defined by users' satisfaction during $90 \%$ of hours. An overall comfort map that quantifies the amount of comfort hours per year for each room was calculated for different periods of the year. The calculation was based on simulations that were executed for $50 \times 50 \mathrm{~cm}$ subdivisions of a horizontal grid that covers all rooms of the apartment unit.

6. Development of improvement strategies: Based on the results from previous simulations, different strategies for the improvement of the building envelope, indoor comfort and energy efficiency were developed. Potential measures associated with the renovation and optimization of the building envelope include:

- The extension of rooms adjacent to existing loggia spaces into the loggia spaces by removal of separating windows.

- Addition of new storage rooms in the middle interior zones of the apartment in order to compensate for the storage space previously provided on the loggias.

- Improvement of the building envelope's thermal insulation.

- Improvement of the building envelope's window-to-wall ratio.

- Improvement of the building envelope's windows and doors.

- Integration of external shading systems for transparent building envelope components.

- Integration of BIPV modules in the building envelope for renewable electricity production.

7. Quantification of improvements: The comparison of simulation results from the existing apartment building and simulation results from the renovated apartment building with optimized building envelope facilitated the quantification of energy demand reduction improvement of indoor comfort for the following indicators:

- Energy demand for heating and cooling

- Comfort hours according to the adaptive comfort model

For the existing apartment and the renovated apartment building the same basic conditions, such as operation schedules (occupation, ventilation, heating and cooling) and users' behaviour were assumed.

8. Virtual building renovation construction using BIM: The BIM model of the existing building was modified and updated in order to create a virtual building renovation model that was based on selected previously described and quantified building renovation measures. The new building envelope components were determined, constructed and assembled in the virtual BIM model using exported geometries parametrically generated in Rhinoceros according to the improved building envelope construction layers defined with the Ladybug tools. The result was a complete BIM model of the renovated apartment building. 
9. Quantification of renewable electricity production: The potential renewable electricity production with BIPV was calculated in average over the period of one year with a dedicated parametric component from Ladybug. The result was balanced with the yearly average final energy demand for heating and cooling of the renovated apartment building.

The definition and selection of specific improvement strategies were based on the repetition of optimization cycles between the previously described phases 7. Development of improvement strategies and 8. Quantification of improvements in order to select the optimal construction for the building envelope renovation system to be included in 9. Virtual building renovation construction using BIM. This iterative process was based on the comparison of simulation results of the existing and optimized building envelopes. The effects of different improvement measures were weighted. The specific research phases are accordingly assigned to specific subsections.

\section{Results}

\subsection{Existing Apartment Building Description}

The virtually reconstructed apartment building is located in the north-eastern part of Seoul, in the district Gireum (Figure 2).

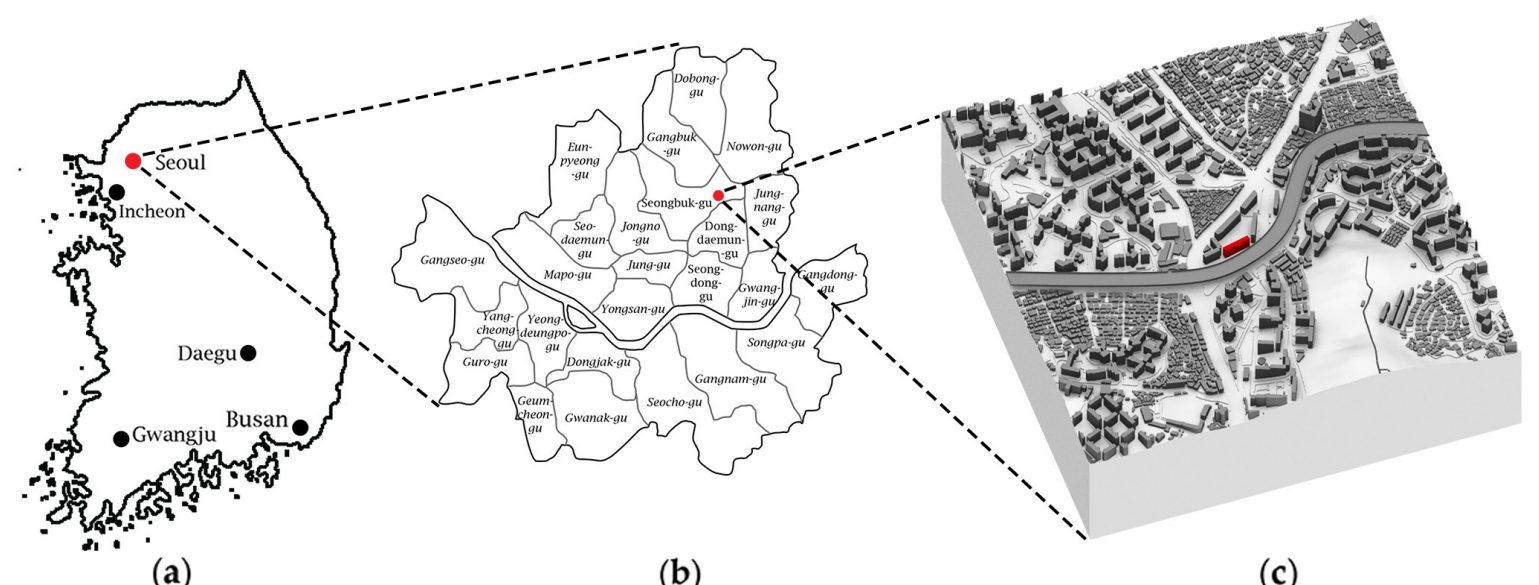

(a)

(b)

(c)

Figure 2. Localization of apartment building 103 (in red) within (a) South Korea, (b) within Seoul and (c) within the Gireum district.

The reference apartment building for this research is building 103, located between the Naebu (Korean: central) highway junction and Gireum Metro station. This building was selected due to its typical and exemplary design, construction and floor plan layout for apartments built during the construction boom period form the 1970s to the 1980s [67].

Building 103 was built in 1992 [68]. The building's age of 26 years exceeds the average lifetime for apartment buildings. The 25-meter-high elevated Naebu Expressway is located directly south of building 103. This infrastructure is associated with comparable high noise, gas and fine dust emissions and blocking solar radiation. The apartment units are heated by floor heating systems (Korean: Ondol $[45,69]$. Heating and hot water production are provided by individual gas boilers for each apartment unit.

Building 103 is part of an apartment district consisting of a flat linear building typology cluster [70]. The building has 15 stories, consisting of similar single apartment units that are located on top of each other. The number of apartment units attached to each other define the building length. The apartment unit (Figure 3) has a gross floor area of approximately $140 \mathrm{~m}^{2}$ and represents one of the most frequent apartment layout and unit size in South Korea [68]. 


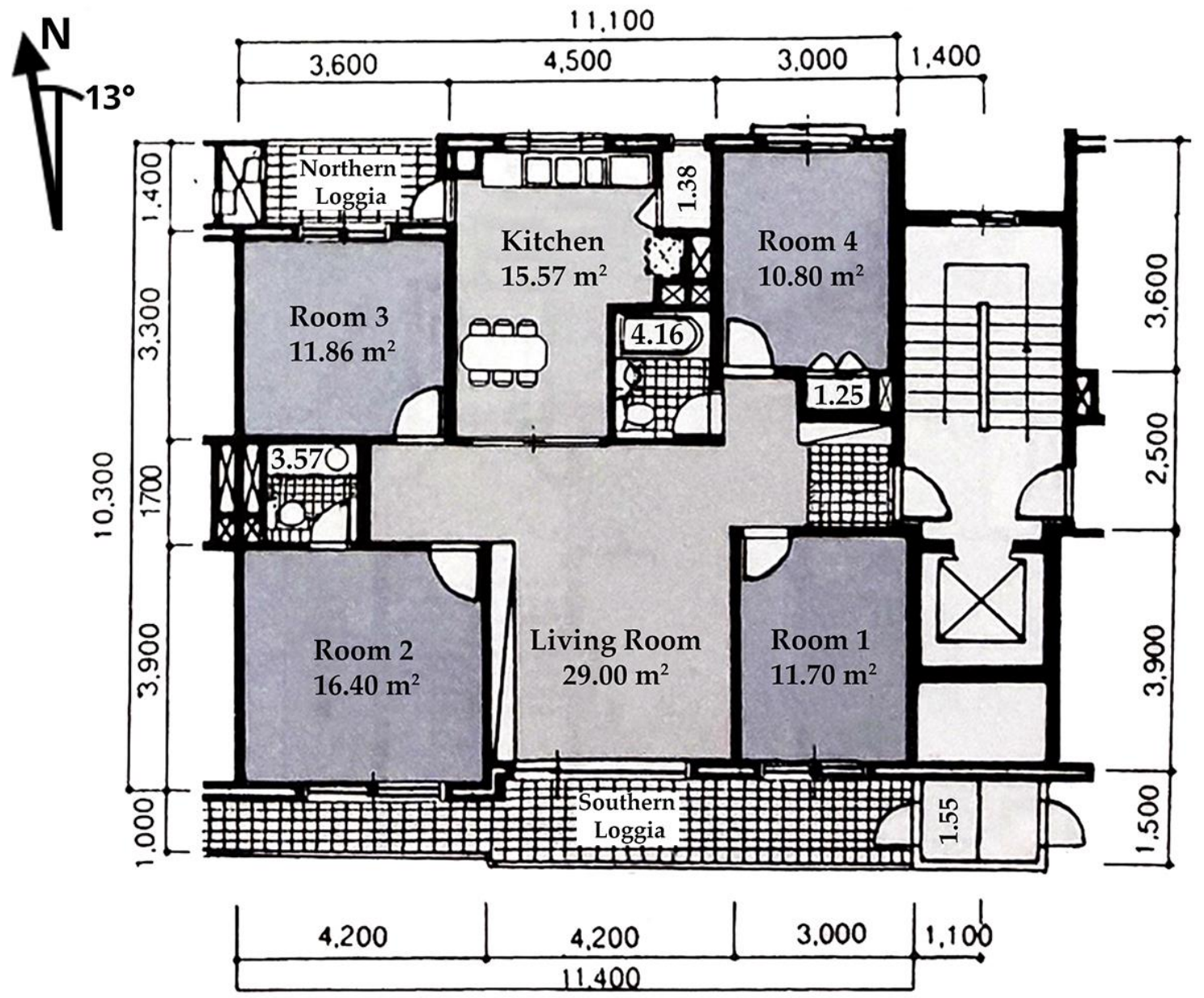

Figure 3. Typical floor plan of an apartment unit and rooms net floor area (in square meters) in the selected building 103 [25].

\subsection{BIM Model of Apartment Building 103}

Building information required for the construction of the BIM model of building 103 was generated by the detailed analysis of similar apartment buildings that were built in the same period. The floor plan layout was based on plans provided by the developer [68]. The construction of building envelope and structure was based on information in recent publications on the common construction of Korean apartments in the designated construction period [71-73]. Additionally, the authors have executed field surveys for the exterior building analysis.

The generated BIM model is a detailed reconstruction of the existing building. The model does not include information on specific building damages and/or deteriorated components. However, damages that are influencing the building performance are well included in the parameters of the energy and comfort simulation operated with the Ladybug tools. The virtual model of apartment building 103, reconstructed with the BIM software Revit facilitated the generation of illustrations such as of the building cubature and envelope (Figure 4) and floor plans (Figure 5). 


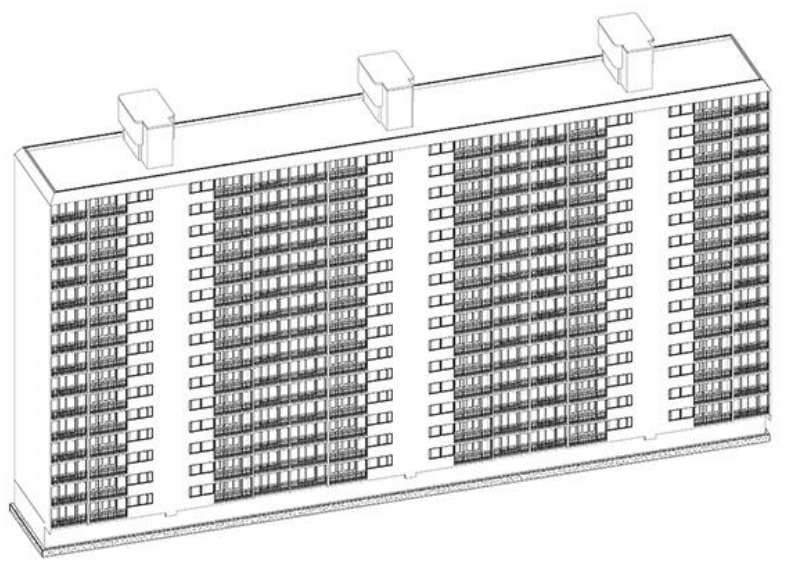

(a)

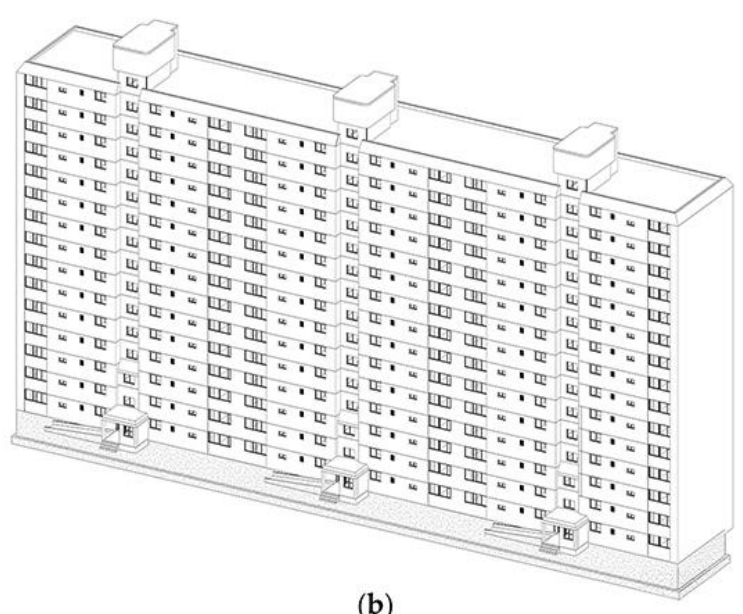

(b)

Figure 4. Isometric view from the South (a) and the North (b) of the virtual apartment building 103 model, reconstructed with the BIM software Revit.

The floor plans of building 103 consist of three clusters with each two apartments aligned in a row. Each cluster includes one staircase and one elevator shaft for vertical and horizontal access of the attached apartment units. The three core unit towers extend to a height of approximately two storeys over the building roof. The first storey consists of the access to the flat rooftop, while the second storey houses the elevator machinery room and a tank for emergency water supply. The building structure consists of load-bearing walls made of in-situ reinforced concrete that are connected through the basement level to the foundation. The level of the building envelope's thermal insulation is defined according to the building energy code from 1987 [74]. External walls are insulated on the inside with polystyrene or polyurethane foam, with a thickness of $50 \mathrm{~mm}$.

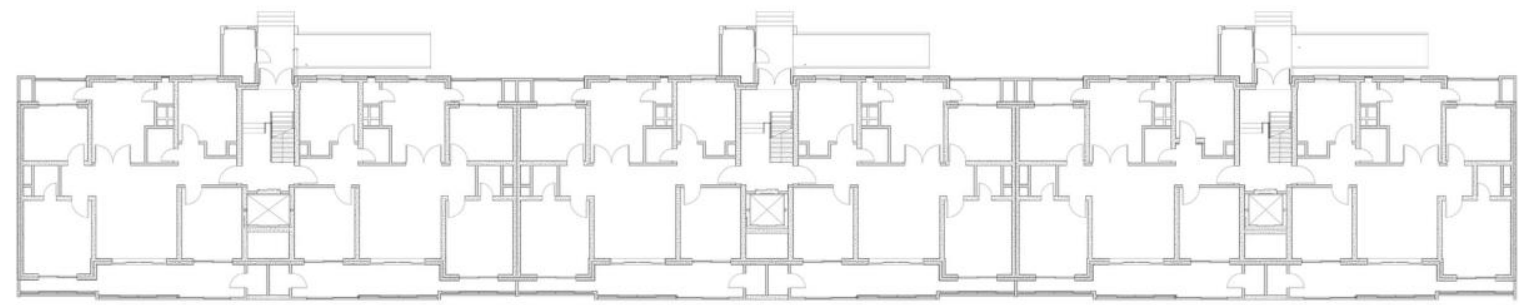

(a)

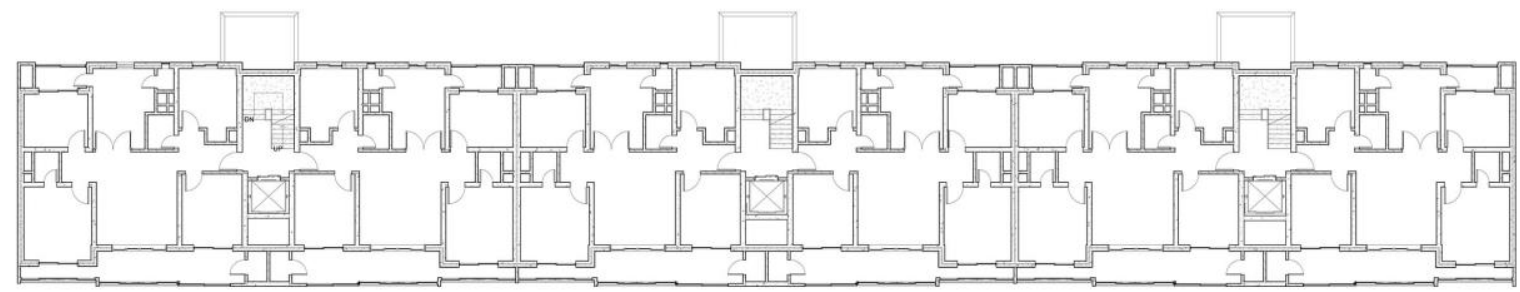

(b)

Figure 5. Ground floor (a) and second to 15 floor plans (b) of apartment building 103 reconstructed with the BIM software Revit.

Loggia walls have a Window to Wall Ratio (WWR) of more than 0.65 . Here opaque components are not thermally insulated. However, the interior walls dividing loggias from the apartment indoors are also insulated with polystyrene panels with a thickness of $50 \mathrm{~mm}$. The building's East and West facades have neither windows nor other openings and are insulated from the inside with polystyrene panels with a thickness of $70 \mathrm{~mm}$. The roof is thermally insulated from the inside with a layer of expanded polystyrene with a thickness of $80 \mathrm{~mm}$. The external walls and the base slab of the basement are insulated from the inside, with polystyrene panels with a thickness of $70 \mathrm{~mm}$. 
All relevant building information is stored in the BIM database of this virtual model and can be used accordingly for the analysis of specific properties of the building and single components. Specific Data, such as summarized general building information (Table 1) have been generated within Revit.

Table 1. Summarized general Building Information for the apartment building 103.

\begin{tabular}{cc}
\hline Index & Value \\
\hline Land plot area & $1386.66 \mathrm{~m}^{2}$ \\
Gross building area & $886.33 \mathrm{~m}^{2}$ \\
Floor number & 15 \\
Floor height & $2.50 \mathrm{~m}$ \\
Room height & $2.30 \mathrm{~m}$ \\
Floor-to-Area Ratio (FAR) & 9.60 \\
Usable area of one apartment unit & $108.04 \mathrm{~m}^{2}$ \\
\hline
\end{tabular}

\subsection{Climate and Solar Radiation Analysis}

The sun path diagram (Figure 6) shows the site map with the $13^{\circ}$ Southeast orientation of building 103 . The diagram also illustrates the yearly sun pass across the sky and the hourly dry bulb temperatures in degrees Celsius. According to the Energyplus climate data for Seoul, average temperatures during winter are $1.68^{\circ} \mathrm{C}$ and reach a minimum of $-11^{\circ} \mathrm{C}$ on 17 January. During summer, the average temperature is $23.82{ }^{\circ} \mathrm{C}$ and reaches a maximum of $31.2^{\circ} \mathrm{C}$ on 20 August. Spring and autumn are very short with transition periods of less than 45 days each before temperatures would decrease or increase to winter and summer averages. The distribution of total annual radiation received by the building envelope in $\mathrm{kWh} / \mathrm{a}$ is illustrated in Figure 7.

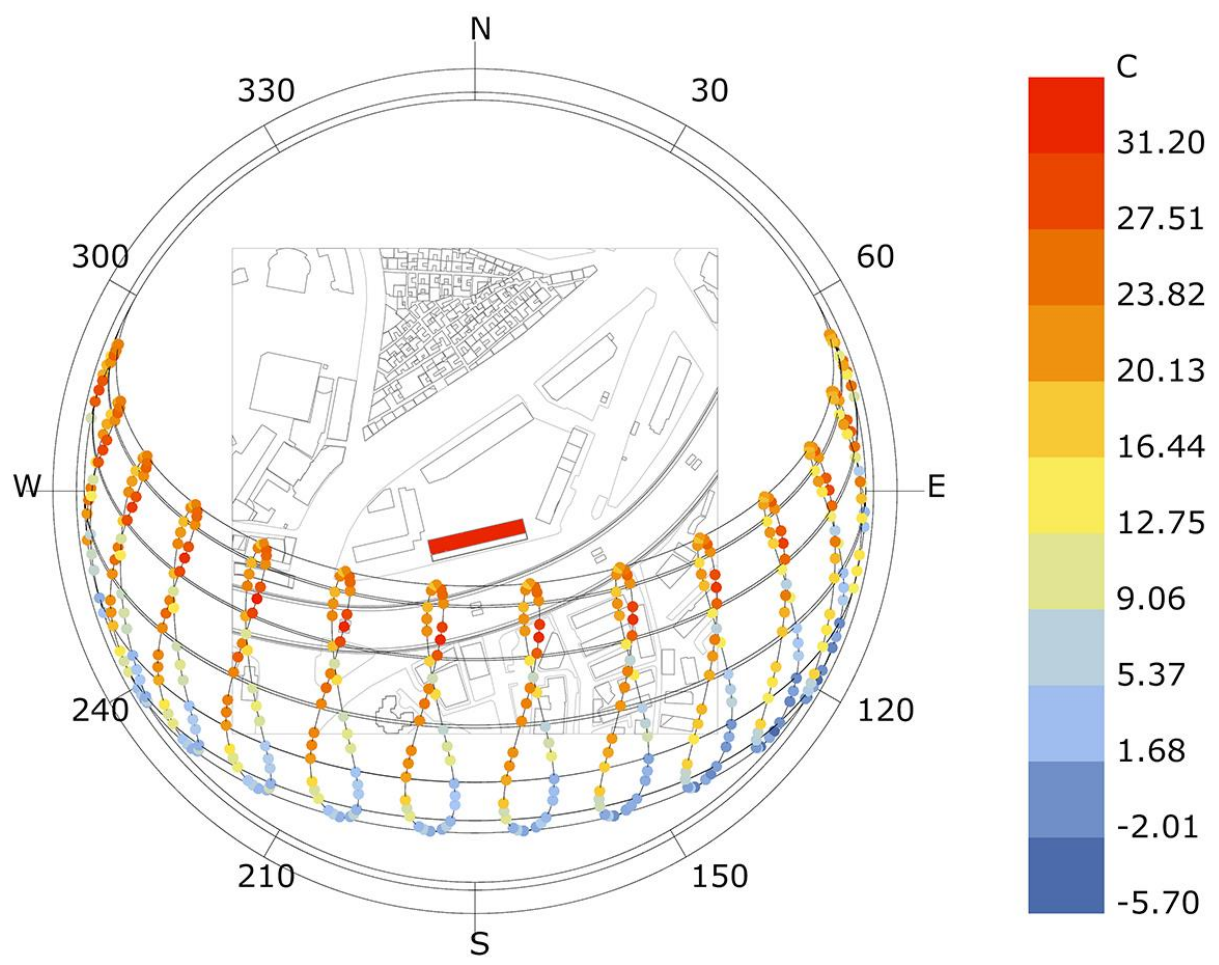

Figure 6. Sun path map with annual analysis and yearly dry-bulb temperature values associated to the position of the sun calculated for the 1st, 15th, 25th and last days of each month. 

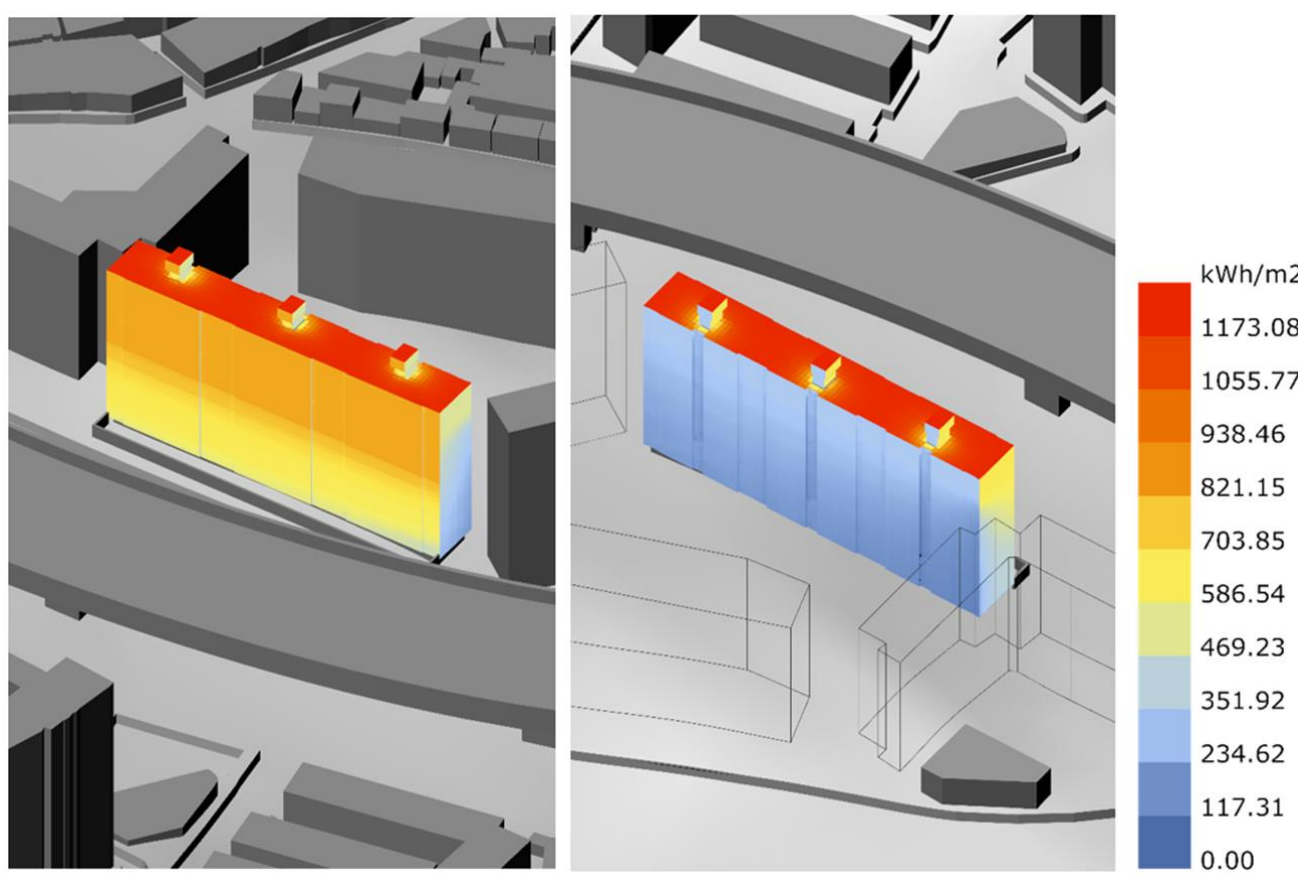

Figure 7. Isometric views from South-East (left) and North-West (right) of building 103 with global radiation received in $\mathrm{kWh} / \mathrm{a}$.

The South façade and roof surfaces received together $70 \%$ of the total solar radiation irradiated on the building envelope. The presence of the elevated expressway in the South limits the solar radiation received by the lower $50 \%$ of the South façade during the winter months. The building orientation and shading from neighbouring buildings significantly limited the radiation on the East, West and North facades. The vertical extensions of the three building cores are shading parts of the roof area.

The global radiation received by the building envelope amounted to approximately $1.80 \mathrm{GWh} / \mathrm{a}$ for the South façade, $0.62 \mathrm{GWh} / \mathrm{a}$ for the North façade and $0.92 \mathrm{GWh} / \mathrm{a}$ for the roof. The East and West façades received $0.13 \mathrm{GWh} / \mathrm{a}$ and $0.18 \mathrm{GWh} /$ a respectively. The radiation analysis provided an estimate of the amount of sunlight hours, by calculating the received direct radiation for each building façade.

\subsection{Existing Building Envelope Analysis}

To determine the U-values of the different building components and the possible presence of thermal bridges, the parametric interface of Ladybug for the programs Energyplus and THERM was used to define material specifications and thermal behaviour. Energyplus calculated the U-value for the different building envelope components based on the definition of specific physical properties of single material layers, such as thickness, thermal conductivity, density and specific heat. THERM simulates the temperature gradient between an indoor temperature of $21^{\circ} \mathrm{C}$ and an outdoor temperature of $-18^{\circ} \mathrm{C}$ through a reference section of the defined constructions. Thickness and U-value of the different building envelope components and interior components are listed in Table 2.

The different window systems of building 103 were simulated with the program LBNL WINDOW and the cumulative U-values of both frame and glazing systems were calculated. The windows consisted of double-glazing in aluminium frames without thermal break. In the calculation of the $\mathrm{g}$-value, the average condition of the windows, such as the accumulation of dirt on the glass surfaces by air pollution were considered. 
Table 2. Thickness and U-values of different building components.

\begin{tabular}{ccc}
\hline Building Component & Thickness (cm) & U-Value (W/m $\mathbf{m}^{\mathbf{2}} \mathbf{)}$ \\
\hline Insulated load bearing wall (northern exterior wall/southern & 34.50 & 0.63 \\
wall between loggia and interior rooms) & 11.50 & 1.63 \\
Exterior loggia wall & 35.00 & 0.46 \\
Roof & 56.50 & 0.45 \\
Basement slab & 12.00 & 1.57 \\
Interior wall (non-structural) & 25.00 & 2.63 \\
Interior wall (structural) & 23.00 & 1.09 \\
\hline Interior slab (ceiling and floor) & & \\
\hline
\end{tabular}

The relative dimensions, solar gain factors and U-values for the different apartment window types are listed in Table 3.

Table 3. Dimensions, U-values and g-values for different apartment window types.

\begin{tabular}{cccc}
\hline Window Type & Dimensions $(\mathbf{1} \times \mathbf{h}) \mathbf{i n} \mathbf{~ c m})$ & U-Value $\left(\mathbf{W} / \mathbf{m}^{\mathbf{2}} \mathbf{K}\right)$ & g-Value \\
\hline Loggia & $380 \times 210$ & 3.163 & 0.65 \\
Glass door & $200 \times 200$ & 3.224 & 0.65 \\
Bedroom Southeast & $250 \times 110$ & 3.019 & 0.65 \\
Bedroom Northwest & $250 \times 110$ & 3.019 & 0.72 \\
Bedroom Northeast & $130 \times 100$ & 3.153 & 0.72 \\
Kitchen & $90 \times 50$ & 3.432 & 0.72 \\
\hline
\end{tabular}

Thermal bridges and temperature gradients of different building envelope components were simulated with the program THERM. Thermal bridges with low indoor surface temperatures have been identified: (i) between the connections of window frames and surrounding walls; (ii) connection between roof slabs and walls; and (iii) the connections between floor slab and walls in the first floor incur the risk of condensation and mould growth.

\subsection{Energy and Thermal Comfort Analysis of Existing Apartment Layout}

\subsubsection{Building Energy Simulation Operation Schedules}

For the simulation of the heating and cooling energy demand, specific operative schedules were defined. Operative schedules model the specific behaviour of residents that influenced the energy related performance of an apartment unit. Each operative schedule assigns a specific control value to each hour for one year. Operative schedules determined the presence of users in the apartment during, the periods when windows were opened for ventilation and the specific indoor comfort temperatures influencing the heating and cooling demand. For the energy simulation of the reference apartment unit, operation schedules consistent with the routine of occupants in Korean apartment were defined. The occupancy determined the presence of people (ppl) in the apartment during the entire day. A value of $0.035 \mathrm{ppl} / \mathrm{m}^{2}$ was based on an average number of approximately 3.5 persons living in each apartment unit. The number of 3.5 people defined for this building simulation was based on the average living space in Korea, of $28.5 \mathrm{~m}^{2}$ per person in 2010 and a usable apartment area of approximately $100 \mathrm{~m}^{2}$. Holiday schedules were defined with an average value of 0.7 and consider the absence of residents during non-working days and weather conditions

Heating and cooling temperature set points were determined according to both temperature requirements defined by the adaptive comfort model [63] and average user-defined comfort temperatures for Korean apartments extrapolated from statistical studies [75]. Heating and cooling schedules were defined for the two periods winter (from 1st of January to the 31st of May and from 1st October to 31st December) and summer (from 1st of June to 3rd September). Due to the short length of spring (April, May) and autumn (September) the transition periods during April and May were 
integrated in the summer schedule and September in the winter schedule. The heating surface in the apartment unit was a floor heating system, natural ventilation was provided via windows and cooling was provided by an air-to-air heat pump system. Lower heating temperatures and higher cooling set points are defined during night hours. An average heating set point temperature of $22^{\circ} \mathrm{C}$ was defined for winter holiday and $25^{\circ} \mathrm{C}$ for summer holiday schedules.

Ventilation schedules defined the periods when each apartment window was opened to a certain degree. An opening degree of 50\% was defined for the single sliding windows of the north-oriented and south-oriented rooms. An opening degree of $30 \%$ was defined for the windows between loggias and outdoors, as well as for the glass doors between loggias and indoors. Ventilation schedules were tailored to minimize the infiltration of cold air during winter, to minimize the infiltration hot air during summer days, but to provide cooling during summer nights by extensive ventilation. The minimum air flow rate during daytime was calculated with a value of $0.002 \mathrm{~m}^{3} / \mathrm{s}$ air per person which was twice as much as the average air flow rate requirement of $0.001 \mathrm{~m}^{3} / \mathrm{s}$ per person standard setting defined in Energyplus [76]. The increased airflow rate was defined in order to provide a sufficient indoor air quality despite of comparable high fine dust concentration [77]. The defined minimum airflow rate per person included the infiltration of outdoor air with an airflow rate of $0.00045 \mathrm{~m}^{3} / \mathrm{s}$, per $\mathrm{m}^{2}$ façade caused by cracks and gaps. The average infiltration airflow rate for new buildings with average to high airtight building envelope is $0.0002 \mathrm{~m}^{3} / \mathrm{m}^{2} \mathrm{~s}$. Accordingly, the airtightness level of apartment building 103 was comparable poor [78]. During the operation of air-to-air heat pumps for active cooling the natural window ventilation airflow rate was reduced. The values for holidays are based on the average absence of people in the apartment during non-working days. The absence is in average $0.35(21 \mathrm{~min} / \mathrm{h})$ for the summer and $0.03(2 \mathrm{~min} / \mathrm{h})$ for the winter period.

In addition to the operation schedules, equipment loads, such as internal heat gains by electric lighting and household appliances, were defined based on the standard average loads defined in Energyplus of $2 \mathrm{~W} / \mathrm{m}^{2}$ for lighting and $6 \mathrm{~W} / \mathrm{m}^{2}$ for other appliances.

\subsubsection{Simulation Model}

For the execution of the energy simulation, the virtual model of the reference apartment unit was constructed in Rhino and converted into zones with Ladybug. Each indoor room was constructed as an individual zone. Through Ladybug, the Energyplus opaque constructions defined in Chapter 3.3 was assigned to the reference apartment unit model surfaces. Accordingly, g-values and cumulative U-values calculated with the program WINDOW were assigned to windows in the Energyplus simulation model of reference apartment unit (Figure 8). Existing thermal bridges in the building construction are not considered in the Energyplus simulation of the reference apartment unit. Loggias and shafts were defined as areas that were not actively heated or cooled by the floor heating system and the cooling system. However, loggias and shaft areas were heat sinks and thermal energy transfer zones in the simulation model and influenced the thermal balance of the apartment. Energyplus zones were named according to the function of the different areas. As Energyplus produced approximation errors for the calculation of interior solar reflections for non-convex spaces, rooms with concave polygonal geometry were partitioned in subzones. Subzones were connected through specific air walls to account for the absence of any physical barrier in single rooms. Since the reference apartment unit was located in the middle of building 103, the separating wall and slab constructions to neighbouring apartment units were defined as adiabatic surfaces.

The model assumed that the condition and physical properties of the building envelope were similar for all apartment units in building 103. Apartment units that were located on the same floor as the reference unit received a similar amount of solar radiation. Therefore, those apartment units had the same heating and cooling energy demand. Apartments located above and below the reference apartment unit received a slightly higher or lower amount of solar radiation. The transition in solar energy radiation intensity received by apartments across the 15 floors of building 103 was assumed 
quasistatic. The location of the reference apartment in between other apartment units was similar to the condition of 60\% (52 of total 90 units) of the apartment units inside building 103.

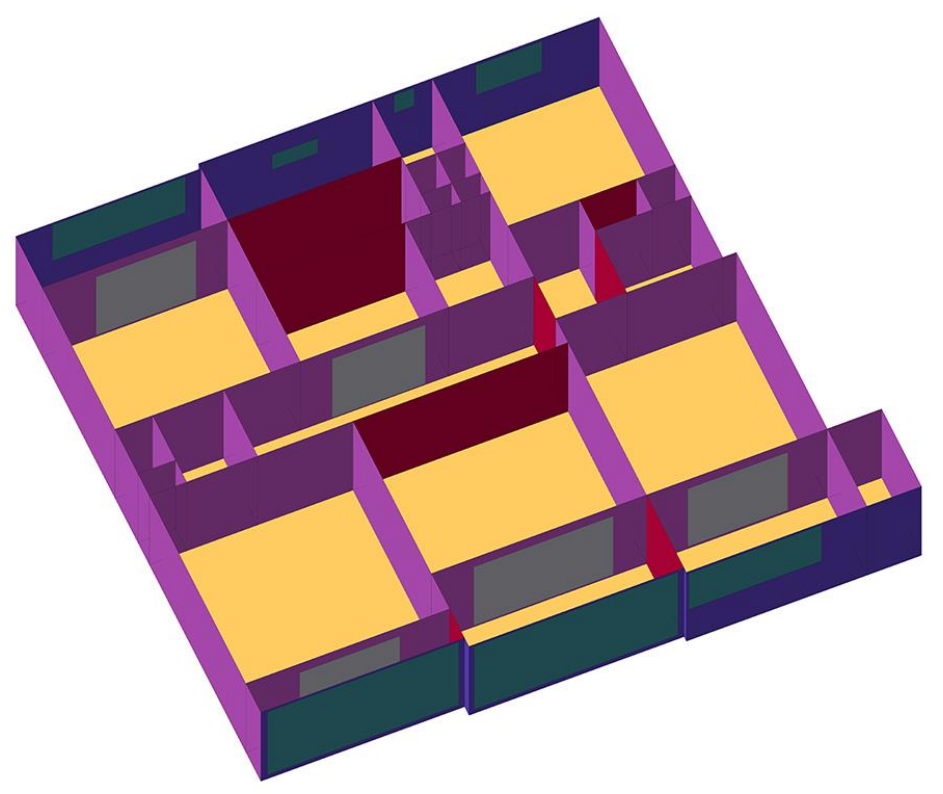

Figure 8. Isometric view of the reference apartment unit's Energyplus simulation model.

\subsubsection{Heating Energy Demand Simulation}

The heating energy demand of the existing reference apartment unit in different rooms per month was simulated with Energyplus. The results in $\mathrm{kWh}$ for different room in specific months and per year are illustrated in Table 4 . The average annual heating energy demand is $130.13 \mathrm{kWh} / \mathrm{m}^{2}$.

Table 4. Heating energy demand of the different rooms in the existing reference apartment unit over the period of one year, in $\mathrm{kWh}$ per month and in total per year.

\begin{tabular}{|c|c|c|c|c|c|c|c|c|c|c|c|c|c|}
\hline Room Name & Total & Jan & Feb & Mar & Apr & May & Jun & Jul & Aug & Sep & Oct & Nov & Dec \\
\hline Kitchen & 3542.52 & 796.21 & 651.24 & 510.86 & 273.97 & 93.62 & 0.00 & 0.00 & 0.00 & 0.00 & 152.24 & 393.89 & 670.49 \\
\hline Closet N & 582.45 & 127.73 & 105.31 & 84.44 & 46.24 & 16.02 & 0.00 & 0.00 & 0.00 & 0.00 & 28.00 & 65.66 & 109.04 \\
\hline Room NE & 1442.25 & 340.60 & 275.22 & 209.31 & 100.01 & 21.41 & 0.00 & 0.00 & 0.00 & 0.00 & 51.96 & 160.34 & 283.40 \\
\hline Bathroom W & 470.58 & 102.70 & 85.42 & 70.17 & 39.63 & 13.26 & 0.00 & 0.00 & 0.00 & 0.00 & 18.34 & 50.84 & 90.22 \\
\hline Corridor & 2872.04 & 656.81 & 537.21 & 422.83 & 223.21 & 67.74 & 0.00 & 0.00 & 0.00 & 0.00 & 95.88 & 309.26 & 559.10 \\
\hline Bathroom N & 595.26 & 128.19 & 106.88 & 87.13 & 49.86 & 18.15 & 0.00 & 0.00 & 0.00 & 0.00 & 27.87 & 65.87 & 111.30 \\
\hline Room SE & 1980.60 & 480.83 & 388.57 & 298.21 & 138.02 & 29.79 & 0.00 & 0.00 & 0.00 & 0.00 & 41.17 & 200.55 & 403.47 \\
\hline
\end{tabular}

The heating energy demand of the existing reference apartment unit was $130.13 \mathrm{kWh} / \mathrm{m}^{2} \mathrm{a}$ according to the Energyplus simulation results. The kitchen had the highest heating energy demand, followed by the corridor and the living room. South-oriented rooms benefit from higher solar gains, which reduced the average heating energy demand by approximately $12 \%$ in comparison with the north-oriented rooms. However, the comparably high U-values and WWR of south-oriented rooms result also in comparably high transmission heat losses. The heating energy demand of the north-oriented rooms was dependent on the specific WWR. The Northeastern room has the lowest heating energy demand due to minimized transmission heat losses. The presence of both north- and south-oriented loggias defines heat sinks for the interior bedroom connected to these non-conditioned spaces. The heat losses result in a lower balance temperature between the two rooms and require therefore a higher heating energy demand to maintain the scheduled heating set points. 


\subsubsection{Cooling Energy Demand Simulation}

The cooling energy demand of the existing reference apartment unit per year and different rooms per month was simulated with Energyplus. The results in $\mathrm{kWh}$ for different rooms in specific months and per year are illustrated in Table 5. The average annual cooling energy demand is $18.14 \mathrm{kWh} / \mathrm{m}^{2}$.

Table 5. Cooling energy demand of the different rooms in the existing reference apartment unit over the period of one year, in kWh per month and in total per year.

\begin{tabular}{clllllllllllll}
\hline Room Name & Total & Jan & Feb & Mar & Apr & May & Jun & Jul & Aug & Sep & Oct & Nov & Dec \\
\hline Kitchen & 331.03 & 0.00 & 0.00 & 0.00 & 0.00 & 0.00 & 2.08 & 128.05 & 195.62 & 5.28 & 0.00 & 0.00 & 0.00 \\
Closet N & 35.77 & 0.00 & 0.00 & 0.00 & 0.00 & 0.00 & 0.14 & 12.80 & 21.90 & 0.94 & 0.00 & 0.00 & 0.00 \\
Room NE & 205.06 & 0.00 & 0.00 & 0.00 & 0.00 & 0.00 & 3.13 & 72.94 & 120.13 & 8.87 & 0.00 & 0.00 & 0.00 \\
Room NW & 307.79 & 0.00 & 0.00 & 0.00 & 0.00 & 0.00 & 3.61 & 118.44 & 177.04 & 8.70 & 0.00 & 0.00 & 0.00 \\
Bathroom W & 23.70 & 0.00 & 0.00 & 0.00 & 0.00 & 0.00 & 0.00 & 7.21 & 15.88 & 0.60 & 0.00 & 0.00 & 0.00 \\
Corridor & 321.94 & 0.00 & 0.00 & 0.00 & 0.00 & 0.00 & 2.40 & 122.37 & 189.53 & 7.65 & 0.00 & 0.00 & 0.00 \\
Bathroom N & 31.05 & 0.00 & 0.00 & 0.00 & 0.00 & 0.00 & 0.00 & 9.97 & 20.28 & 0.80 & 0.00 & 0.00 & 0.00 \\
Room SW & 452.02 & 0.00 & 0.00 & 0.00 & 0.00 & 0.00 & 7.78 & 160.90 & 256.92 & 26.41 & 0.00 & 0.00 & 0.00 \\
Living Room & 475.54 & 0.00 & 0.00 & 0.00 & 0.00 & 0.00 & 6.59 & 180.24 & 271.18 & 17.53 & 0.00 & 0.00 & 0.00 \\
Room SE & 335.12 & 0.00 & 0.00 & 0.00 & 0.00 & 0.00 & 3.75 & 125.04 & 194.91 & 11.42 & 0.00 & 0.00 & 0.00 \\
\hline
\end{tabular}

The cooling energy demand of the existing reference apartment unit was $18.14 \mathrm{kWh} / \mathrm{m}^{2} \mathrm{a}$ according to the Energyplus simulation results. This amount was similar to $14 \%$ of the annual heating energy demand. The cooling energy demand was smaller than the heating energy demand due to the comparable short summer period with intensive cooling demand during July and August and the reduced operation time of the cooling system during the months June and September. Night ventilation and higher cooling set points during afternoon and night hours during these months lowered the cumulative cooling energy required. For the south-oriented rooms, the high U-values of the loggia windows contributed to heat gains from outdoors, notwithstanding the relatively low g-value of the glazing. Longer ventilation periods and related air flow rates during the summer compared with the winter contributed to increased indoor heat gains.

North-oriented rooms with a lower WWR and glazing area, such as the kitchen and the room in the northwest, had a lower cooling energy demand due to reduced solar gains. In contrast, the north-western rooms had a higher cooling energy demand. The received solar radiation contributed to increased heat gains due to the lower sun altitude and bigger glazing area with a higher g-value (0.72) compared to the southern rooms with a g-value of 0.65 .

\subsubsection{Adaptive Comfort Map of the Apartment Unit}

The percentages of comfort hours in relation to all hours of a year were illustrated for all rooms inside the reference apartment unit by means of simplified ground floor plans in Figure 9 for a whole year (Figure 9a), for the winter and heating period from 1st January to 31st May (Figure 9b) and the summer and cooling period from 1st of June to 30th September (Figure 9c).

The average percentage of comfort hours during the period of one year was between $80-90 \%$. However, the difference in comfort hours between the winter and summer periods was $35 \%$. During the winter and heating period from 1st January to 31st May the percentage of indoor comfort hours was $100 \%$ in all rooms. The provision of this comfort was associated with a high heating demand of approximately $130 \mathrm{kWh} / \mathrm{m}^{2}$ a. During summer, the percentage of indoor comfort hours was in average $65 \%$ with significant differences in comfort hours between single rooms. The summer comfort analysis showed the relation between the position of each reference apartment room and the percentage of comfort hours. Rooms located adjacent to large loggias or located in the middle of the apartment have higher discomfort hour percentages than rooms without loggias or located behind smaller loggias. 


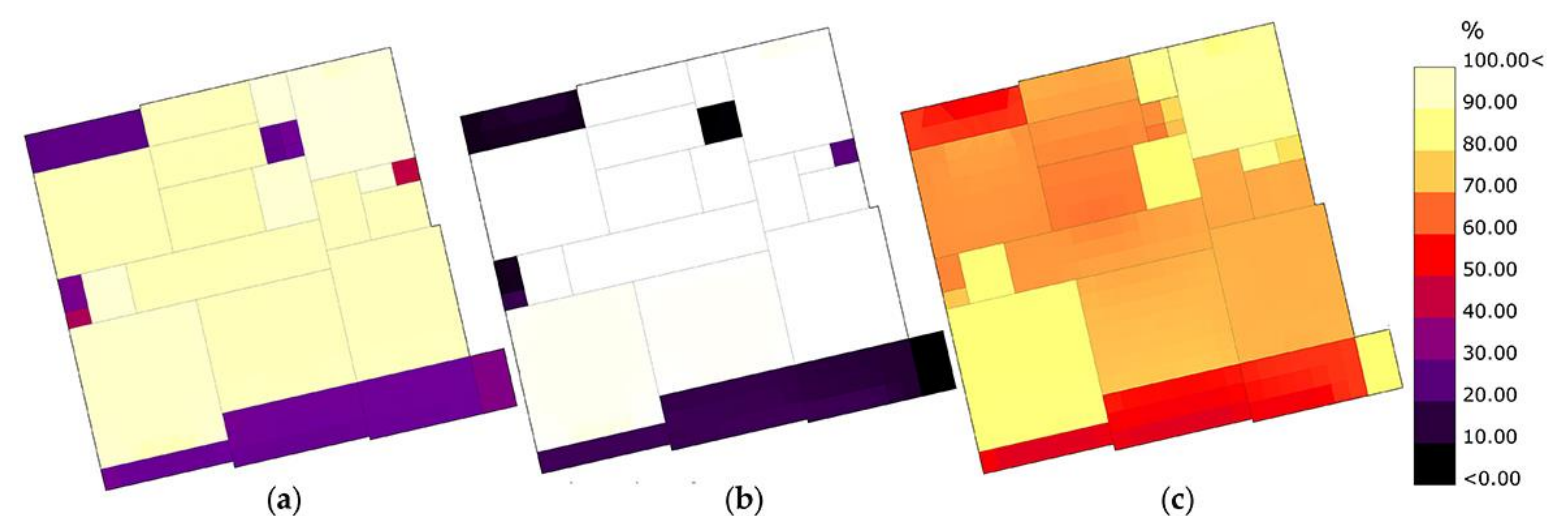

Figure 9. Reference apartment unit comfort maps on simplified floor plans with illustration of comfort hours' percentages in relation to all hours for different periods, (a) the period of one year; (b) winter and heating period from 1st January to 31st May; (c) summer and cooling period from 1st of June to 30th September.

\subsection{Definition of Building Envelope Improvement Measures}

Based on the analysis of the existing energy demand and comfort of the reference apartment unit, two main renovation measures were developed for building 103: (i) the extension of interior rooms by integration of loggias and (ii) the design of an improved building envelope system to be mounted on the existing building construction. The development of the renovation system in this research was based on the analysis of Korean apartment refurbishment projects that were realized between 2000 and $2014[79,80]$ and the survey of renovation strategies for residential buildings that were preferable and acceptable among apartment residents [81]. Such realized refurbishment projects involved primarily the integration of loggias into indoors. Some projects included the construction of new loggias by horizontal extension of the existing apartments [82]. The energy efficient renovation of apartments in South Korea was supported by the amendment of the National Housing Act, Art. 2 in 2012 [83]. The amendment allowed apartment owners and construction companies to form a partnership for the refurbishment of apartment buildings. An extension of the existing usable floor area of apartment units by up to $40 \%$ was allowed if the renovation would be associated with significant improvement of the building's energy efficiency, particularly by lowering transmission heat losses of building envelopes. However, in the framework of this research and the renovation of building 103 no horizontal building extension was considered. The horizontal extension of the apartment units would limit the comparability of the apartment building performance before and after the renovation, particularly regarding daylighting. A horizontal extension of the apartment building would significantly decrease the amount of overall daylight received by the areas in the middle of the apartment units.

In order to compensate the storage area loss due to the integration of loggias in the adjacent rooms, two new storage rooms were included in the middle of the apartment unit in the north-western and south-eastern bedrooms. Due to the absence of storage rooms in Korean Apartments, loggias were often used as storage areas, for example, for household appliances and goods, as well as for the drying of laundry. Goods stored in loggias reduced the amount of daylight penetrating to the indoors of apartment units. Therefore, the addition of two new storage rooms in the southwestern and south-eastern bedrooms contributed to the adapted use of darker apartment areas and improved overall daylighting by unblocking window areas from stored goods. Additional extensive modifications to the apartment unit's interior layout were not foreseen in the renovation plan. Excepted from the installation of BIPV panels in the façade for renewable electricity production, no major modifications of the building services engineering system, including heating and cooling were considered in the building renovation. The reference apartment unit floor plan layouts before and after renovation are shown in Figure 10. 


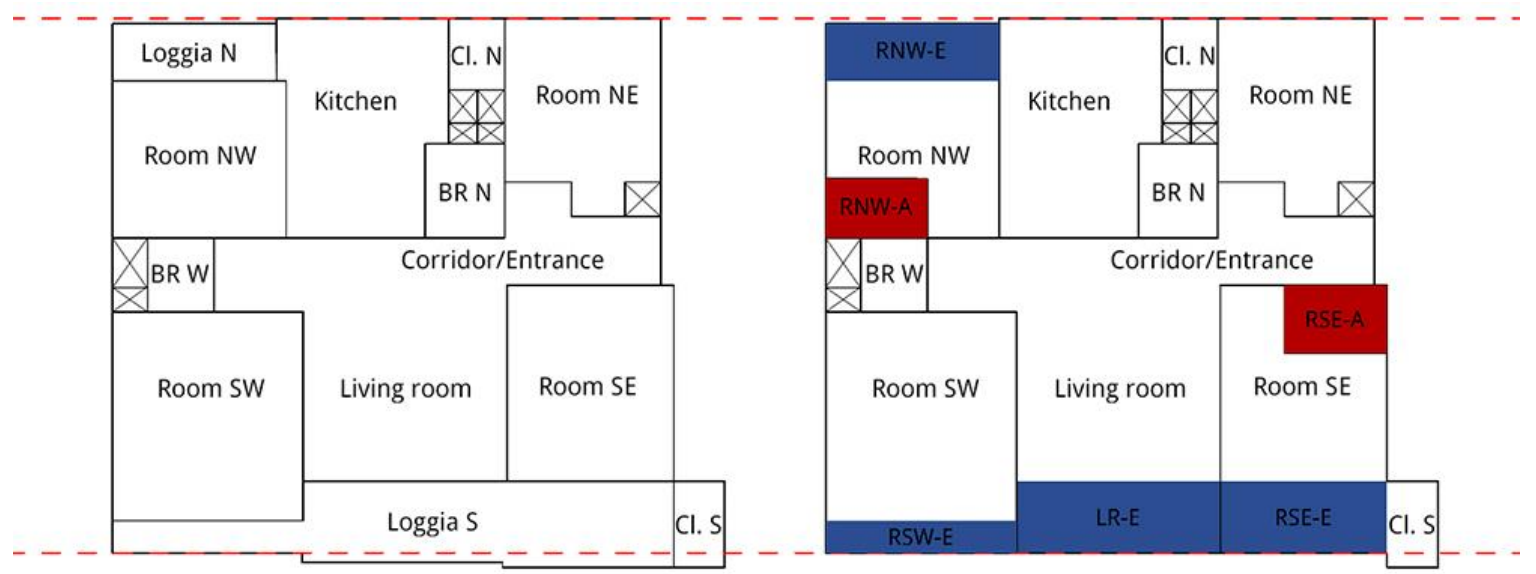

Figure 10. Reference apartment unit floor plan layouts before (left) and after (right) renovation. Loggia spaces that have been integrated in the adjacent rooms are marked blue. Additional storage rooms are marked red.

The existing usable indoor apartment area was extended by $17 \%$ through the expansion of indoors into the south- and north-oriented loggias. The modular building envelope system for the proposed building renovation was based on pre-fabricated components. Each single component module consisted of multiple material layers. The parametric definition of this building envelope component system included materials with good structural and weatherproof properties. The windows were designed with an average sound reduction of $41 \mathrm{~dB}$ to reduce the impact of traffic noise indoors. An airtight building envelope with optimized window configuration and position facilitated controlled cross ventilation and improved indoor air exchange. The description of the functional layers and materials of the building envelope renovation system components utilized in this research is provided in Table 6. The construction layers of an exemplary façade component and the single layers are illustrated in Figure 11. The construction of an exemplary roof component is illustrated in Figure 12. The numbers of the component layers refer to the detailed description of the building envelope system in Table 6.

Table 6. Description of modular building envelope renovation system construction, with specification of the individual layers from 0 (inside) to 7 (outside), name, component configuration and layer depths.

\begin{tabular}{|c|c|c|c|}
\hline Layer No. & Name & Component Configuration and Materials & Depth \\
\hline 0 & Indoors building envelope layer & Gypsum boards \& wood frame & Depth: 8-10 cm \\
\hline 1 & Support structure & Stainless steel frames & Depth: $4-6 \mathrm{~cm}$ \\
\hline 2 & Construction support frame & $\begin{array}{l}\text { Timber frame \& stainless steel rail connectors } \\
\text { to layers } 1 \& 3\end{array}$ & Depth: $6-8 \mathrm{~cm}$ \\
\hline 3 & Thermal insulation panel & $\begin{array}{l}\text { Mineral glass wool [84], timber frame \& } \\
\text { aluminium foil (vapor barrier) }\end{array}$ & Depth: $20 \mathrm{~cm}$ \\
\hline 4 & Construction support frame & $\begin{array}{l}\text { Timber frame, stainless steel connectors \& } \\
\text { plastic membrane (waterproof barrier) }\end{array}$ & Depth: $6-8 \mathrm{~cm}$ \\
\hline 5 & Window component & Timber frame, double glazing \& rubber gasket & Depth: $10-15 \mathrm{~cm}$ \\
\hline 6 & Solar blind system & Recycled plastic \& stainless steel & Depth: $8 \mathrm{~cm}$ \\
\hline 7 & $\begin{array}{l}\text { Mounting System \& } \\
\text { 1. Cladding } \\
\text { 2. Cladding }\end{array}$ & $\begin{array}{l}\text { Stainless steel } \\
\text { 1. Glass, plastic film, multi crystalline silicon } \\
\text { (PV) \& aluminium frame } \\
\text { 2. Recycled plastic panels [85] }\end{array}$ & $\begin{array}{l}\text { Depth: } 10 \mathrm{~cm} \\
\text { 1. Depth: } 2 \mathrm{~cm} \\
\text { 2. Depth } 0.5 \mathrm{~cm}\end{array}$ \\
\hline$\Sigma$ & $\begin{array}{l}\text { Complete component window } \\
\text { 1. Complete component cladding } 1 \\
\text { 2. Complete component cladding } 2\end{array}$ & $\begin{array}{l}\text { Multiple (see above) } \\
\text { Multiple (see above) } \\
\text { Multiple (see above) }\end{array}$ & $\begin{array}{l}\text { Depth: } 42.5 \mathrm{~cm} \\
\text { 1. Depth: } 55 \mathrm{~cm} \\
\text { 2. Depth: } 43 \mathrm{~cm}\end{array}$ \\
\hline
\end{tabular}




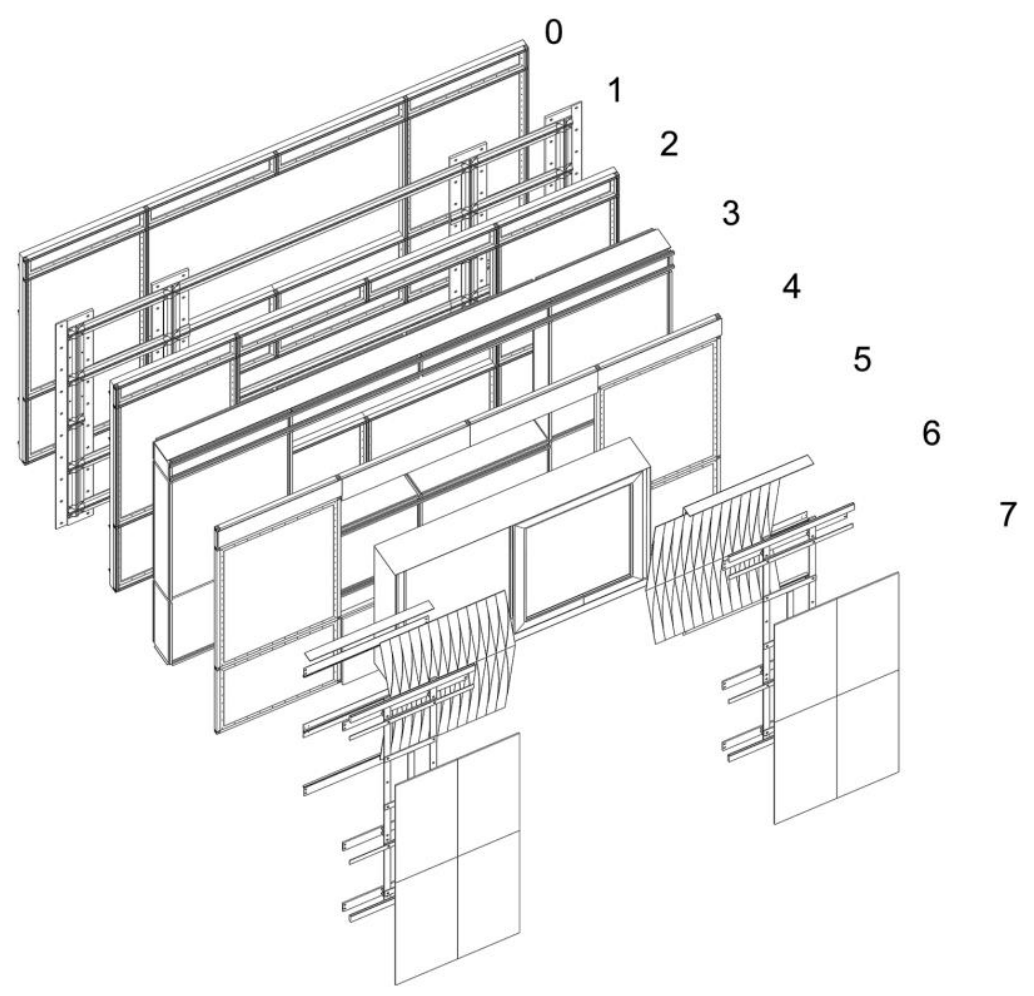

Figure 11. Isometric view of an exemplary façade component with axonometric illustration of the individual layers. The component layer numbers from 0 (inside) to 7 (outside) refer to the detailed description of the building envelope system in Table 6.

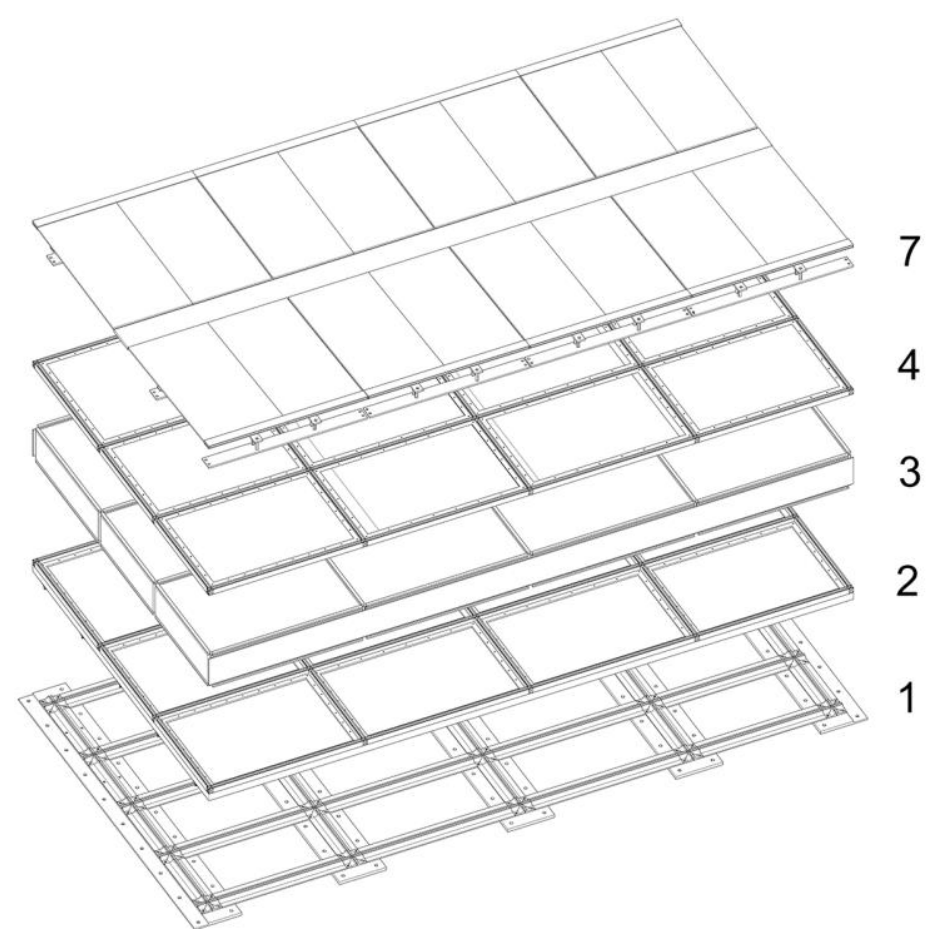

Figure 12. Isometric view of an exemplary roof component with axonometric illustration of the individual layers. The component layer numbers from 1 (inside) to 7 (outside) refer to the detailed description of the building envelope system in Table 6.

An assessment of environmental impacts of a range of construction products included in the wecobis [86] and oekobau [87] databases were executed in order to support the selection of 
most appropriate materials for the building envelope component construction. Materials were compared regarding their impact on greenhouse gasses emissions, resources-and primary energy consumption and their average lifespan. Sustainability assessment and certification criteria of the German Green Building Council DGNB (German: Deutsche Gesellschaft für nachhaltiges Bauen) ENV.1 (ecological footprint), ENV.2.1 (resources and energy use) and TEC.1.6 (construction/deconstruction configuration and reutilization) were used as base evaluation criteria for the environmental benchmark analysis of alternative construction materials and products [88] within this research. The benchmark analysis of the environmental impact for alternative materials provided a selection of specific construction materials satisfying performance requirements, while having low environmental impacts and an average life span of at least 40 years.

The temperature gradients through the different constructions of the improved building envelope system were simulated with THERM.

After renovation, the formation of the existing thermal bridges between the connection between roof slabs and walls and the connections between floor slab and walls in the first floor have been minimized. A thermal bridge remains between the window and the opaque building renovation component due to the U-value differences.

To calculate the cumulative frame and glazing U-value of the windows installed in the improved envelope components, the program WINDOW was used. The WINDOW U-value simulation takes in consideration available frame and glazing products in South Korea to calculate the minimum U-value that can be achieved with locally available materials and components. Even though advanced glazing systems with low thermal transmission coefficients for residential buildings were available, the average $\mathrm{U}$-value of windows available on the market was approximately $2.4 \mathrm{~W} / \mathrm{m}^{2} \mathrm{~K}$ [73]. Envelope component windows were constructed with timber frames and double clear glazing. The resulting average simulated U-value is $2.0 \mathrm{~W} / \mathrm{m}^{2} \mathrm{~K}$ and the g-value was 0.8 . An overview of the different windows used in the construction of the different façade modules, their dimensions, opening types, U-values and the specific WWRs achieved with a certain number of windows in the different rooms is summarized in Table 7.

Table 7. Windows in specific rooms with specification of dimensions, opening types, U-values and WWRs used in the improved building envelope construction.

\begin{tabular}{|c|c|c|c|c|c|}
\hline Window & Amount & Dimensions $(1 \times \mathrm{h}$ in $\mathrm{cm})$ & Opening Type & U-value $\left(\mathrm{W} / \mathrm{m}^{2} \mathrm{~K}\right)$ & WWR \\
\hline Southern bedrooms & 2 & $200 \times 125$ & Sliding & 1.99 & $28 \%(\mathrm{SE} / \mathrm{SW})$ \\
\hline Living room & 3 & $90 \times 145$ & Tilt & 2.00 & $35 \%$ \\
\hline Northern bedrooms & 4 & $90 \times 125$ & Flush/Tilt & 2.02 & $\begin{array}{c}22 \%(\mathrm{NE}) \\
23 \%(\mathrm{NW})\end{array}$ \\
\hline Kitchen & 2 & $90 \times 50$ & Sliding & 2.28 & $10 \%$ \\
\hline
\end{tabular}

\subsection{Energy and Thermal Comfort Analysis of Renovated Apartment Layout with Improved Envelope}

\subsubsection{Heating Energy Demand Simulation}

The Energyplus simulation model of the renovated apartment layout is shown in Figure 13. The heating energy demand for each room of the renovated apartment unit with improved envelope is summarized in Table 8. The heating energy demand for the new storage spaces in the northwest and southeast was included in the demand of the north-western and south-eastern bedrooms. 


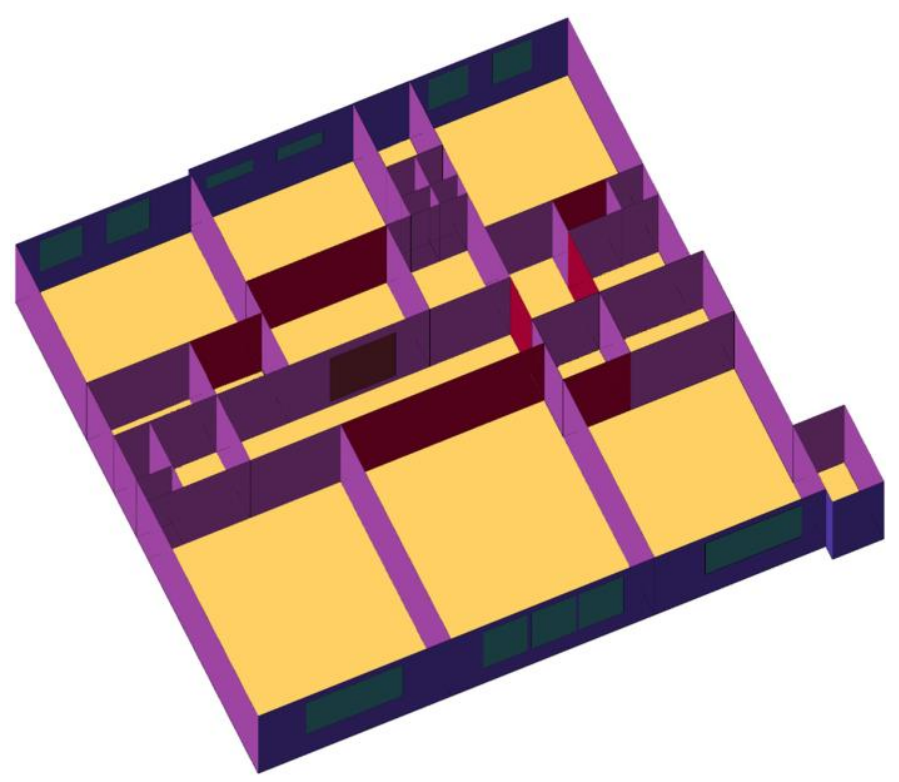

Figure 13. Isometric view of the Energyplus model of the renovated reference apartment unit with new room layout.

Table 8. Annual heating energy demand in $\mathrm{kWh}$ for single rooms of the renovated reference apartment unit with an average heating energy demand of $55.9 \mathrm{kWh} / \mathrm{m}^{2}$.

\begin{tabular}{|c|c|c|c|c|c|c|c|c|c|c|c|c|c|}
\hline Room Name & Total & Jan & Feb & Mar & Apr & May & Jun & Jul & Aug & Sep & Oct & Nov & Dec \\
\hline Kitchen & 1215.44 & 313.97 & 248.33 & 179.91 & 71.73 & 2.45 & 0.00 & 0.00 & 0.00 & 0.00 & 19.03 & 129.81 & 250.22 \\
\hline Closet N & 165.44 & 40.17 & 32.74 & 26.57 & 12.28 & 0.23 & 0.00 & 0.00 & 0.00 & 0.00 & 3.53 & 17.65 & 32.28 \\
\hline Room NE & 990.16 & 257.31 & 202.57 & 146.22 & 55.70 & 1.17 & 0.00 & 0.00 & 0.00 & 0.00 & 15.87 & 106.46 & 204.87 \\
\hline Room NW & 940.15 & 250.41 & 195.39 & 136.32 & 47.12 & 0.48 & 0.00 & 0.00 & 0.00 & 0.00 & 11.91 & 99.82 & 198.69 \\
\hline Bathroom W & 142.05 & 36.21 & 29.21 & 22.93 & 9.05 & 0.00 & 0.00 & 0.00 & 0.00 & 0.00 & 0.54 & 14.46 & 29.66 \\
\hline Corridor & 1013.60 & 270.93 & 214.78 & 154.22 & 46.59 & 0.20 & 0.00 & 0.00 & 0.00 & 0.00 & 4.11 & 105.42 & 217.35 \\
\hline Bathroom N & 188.16 & 47.28 & 38.23 & 29.78 & 12.62 & 0.00 & 0.00 & 0.00 & 0.00 & 0.00 & 1.90 & 19.92 & 38.43 \\
\hline Room SW & 801.47 & 227.17 & 175.54 & 116.63 & 26.22 & 0.01 & 0.00 & 0.00 & 0.00 & 0.00 & 1.27 & 73.15 & 181.48 \\
\hline Living Room & 1417.53 & 388.57 & 306.74 & 210.61 & 53.97 & 0.23 & 0.00 & 0.00 & 0.00 & 0.00 & 5.38 & 143.49 & 308.55 \\
\hline Room SE & 899.01 & 253.84 & 196.83 & 131.64 & 29.64 & 0.01 & 0.00 & 0.00 & 0.00 & 0.00 & 1.36 & 82.32 & 203.37 \\
\hline
\end{tabular}

The improved building envelope and room configuration of the renovated reference apartment unit contribute to an overall reduction of $57 \%$ of the annual heating energy demand, from 130.13 before renovation to $55.99 \mathrm{kWh} / \mathrm{m}^{2}$ a after renovation. The reduction of U-values of the opaque building envelope and windows contribute to the reduction of transmission heat losses and related heating energy demand of the apartment. However, the U-values of the new windows had a comparably high $\mathrm{U}$-value of $2.0 \mathrm{~W} / \mathrm{m}^{2} \mathrm{~K}$, which was only a reduction of approximately $-1 \mathrm{~W} / \mathrm{m}^{2} \mathrm{~K}$ compared to the existing condition. Therefore, transmission heat losses through the glazing contribute significantly to the comparable high heating energy demand of the apartment unit after renovation. The kitchen and the living room have also after renovation the highest room specific heating energy demand because the indoor room configuration had remained similar to the situation before the renovation. The kitchen WWR could not be altered substantially due to the presence of fixtures and kitchen furniture permanently installed in proximity of the exterior wall.

During May and October, the improved thermal insulation of the building envelope reduces heat losses, while improved g-values facilitate increased solar heat gains in the indoors. Accordingly, the required heating energy in May and October was significantly reduced.

The monthly heating energy demand standard deviation of individual rooms was $455.81 \mathrm{kWh}$ for the renovated apartment unit and $669.88 \mathrm{kWh}$ for the existing apartment unit. The lower standard deviation was caused by the increased average WWR of the north-oriented rooms $(+3 \%)$ in the renovated apartment unit, which was caused by the decrease of the average WWR of the south-oriented rooms $(-40 \%)$ and low opaque building envelope component U-values. 


\subsubsection{Cooling Energy Demand Simulation}

The cooling energy demand of the renovated reference apartment unit was simulated with Energyplus. The annual cooling energy demand of the entire apartment unit was $16.08 \mathrm{kWh} / \mathrm{m}^{2} \mathrm{a}$ and is listed in $\mathrm{kWh}$ for the different months for the specific rooms in Table 9.

Table 9. Cooling energy demand of specific renovated reference apartment unit rooms for the different months of one year.

\begin{tabular}{cccccccccccccc}
\hline Room Name & Total & Jan & Feb & Mar & Apr & May & Jun & Jul & Aug & Sep & Oct & Nov & Dec \\
\hline Kitchen & 268.37 & 0.00 & 0.00 & 0.00 & 0.00 & 0.00 & 2.39 & 97.46 & 160.95 & 7.56 & 0.00 & 0.00 & 0.00 \\
Closet N & 16.04 & 0.00 & 0.00 & 0.00 & 0.00 & 0.00 & 0.01 & 4.16 & 11.15 & 0.72 & 0.00 & 0.00 & 0.00 \\
Room NE & 228.61 & 0.00 & 0.00 & 0.00 & 0.00 & 0.00 & 3.30 & 81.44 & 134.61 & 9.26 & 0.00 & 0.00 & 0.00 \\
Room NW & 258.21 & 0.00 & 0.00 & 0.00 & 0.00 & 0.00 & 3.91 & 92.04 & 151.84 & 10.42 & 0.00 & 0.00 & 0.00 \\
Bathroom W & 21.10 & 0.00 & 0.00 & 0.00 & 0.00 & 0.00 & 0.07 & 5.81 & 13.78 & 1.44 & 0.00 & 0.00 & 0.00 \\
Corridor & 254.20 & 0.00 & 0.00 & 0.00 & 0.00 & 0.00 & 2.49 & 89.31 & 152.98 & 9.41 & 0.00 & 0.00 & 0.00 \\
Bathroom N & 28.71 & 0.00 & 0.00 & 0.00 & 0.00 & 0.00 & 0.07 & 8.05 & 19.01 & 1.58 & 0.00 & 0.00 & 0.00 \\
Room SW & 323.09 & 0.00 & 0.00 & 0.00 & 0.00 & 0.00 & 5.90 & 109.17 & 184.78 & 23.25 & 0.00 & 0.00 & 0.00 \\
Living Room & 484.56 & 0.00 & 0.00 & 0.00 & 0.00 & 0.00 & 7.41 & 167.80 & 280.65 & 28.71 & 0.00 & 0.00 & 0.00 \\
Room SE & 349.85 & 0.00 & 0.00 & 0.00 & 0.00 & 0.00 & 6.18 & 117.24 & 201.81 & 24.62 & 0.00 & 0.00 & 0.00 \\
\hline
\end{tabular}

The average annual cooling energy demand of the renovated reference apartment unit was only $11 \%$ lower as the cooling energy demand of $18.14 \mathrm{kWh} / \mathrm{m}^{2} \mathrm{a}$ of the existing apartment unit. The higher monthly cooling energy demand was caused by the extension of rooms into the loggia spaces with direct interface of the windows with the outdoors, increased exposure of windows to direct solar radiation during the summer months from June to September, as well as increased WWR and g-values of the renovated apartment envelope, particularly in the living room and the south-eastern bedroom.

Natural ventilation of hot outdoor air and solar radiation during summer days were the main heat sources that increased the cooling energy demand of the north-eastern and south-eastern bedrooms, as well as the living room. Approximately $40 \%$ of the renovated apartment unit rooms' monthly cooling energy demand values during June, August and September were higher than the values of the existing apartment unit. However, the average increase of the cooling energy demand for these monthly values was only $3.73 \mathrm{kWh} /$ month, whereas the average decrease in cooling energy for the remaining months $(60 \%$ of the renovated apartment unit rooms' monthly cooling energy demand values) was $18.10 \mathrm{kWh} /$ month. The overall decrease of annual cooling energy demand of the renovated apartment unit was caused by the lower U-values of the building envelope and the operation of the external shading system.

\subsubsection{Adaptive Comfort Map of the Renovated Reference Apartment Unit}

The adaptive comfort map floor plan of the renovated reference apartment unit is shown in Figure 14, differentiated in (Figure 14a) the annual amount of comfort hours, (Figure 14b) the comfort hours from 1st January to 31st May and (Figure 14c) the comfort hours from 1st June to 30th September.

Annual average percentage of comfort hours in the renovated apartment unit rooms (Figure 14a) in relation to total hours was $90-100 \%$. This percentage was an increase of approximately $10 \%$ compared to the percentage in the existing apartment unit rooms of $80-90 \%$. During the period from 1st January to 31st May (Figure 14b) the average percentage of comfort hours in the renovated apartment unit rooms was minimally reduced from $100 \%$ in the existing apartment unit rooms to $97 \%$ of comfort hours. Particularly the high transmission heat losses through the windows with comparable high U-values contribute to uncomfortable low indoor temperatures near the façade. During the period from 1st June to 30th September (Figure 14c) the percentages of comfort hours were significantly improved for all rooms in the renovated apartment unit (Figure 14a) compared to the rooms in the existing apartment unit. The comfortable hours increased by $10 \%$, the highest comfort increase compared to the other 9 months, to a mean value of $82 \%$. 


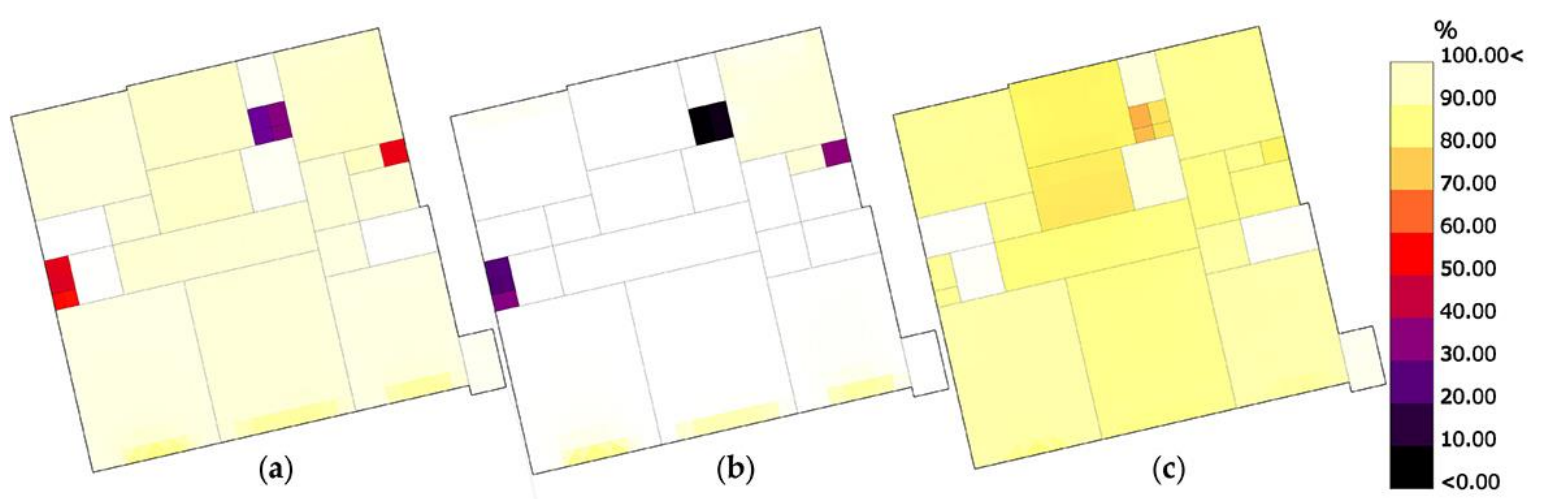

Figure 14. Floor plans with adaptive comfort maps of the renovated reference apartment unit illustrate (a) the annual amount of comfort hours, (b) the comfort hours from 1 January to 31 May and (c) the comfort hours from 1 June to 30 September. Comfort hours are illustrated in percentages of total hours from black $(0 \%)$ to white $(100 \%)$.

The comparison of comfort hours according to the adaptive model between the existing and the renovated apartment unit rooms is shown in Table 10. According to the annual comfort hour analysis, only the kitchen did reach the $90 \%$ annual comfort hours' threshold. The reason was the low WWR and the room depth of the kitchen that favored heat dissipation. However, after renovation comfortable hours in the kitchen increased by approximately $5 \%$, which was similar to the average increase in comfortable hours per year in all rooms. In the living room comfortable hours improve by approximately $6 \%$.

Table 10. Overview of comfortable hours in percentage of total hours for selected rooms in the existing and renovated reference apartment unit according to the adaptive model. For the renovated apartment unit rooms also the improvement of comfortable hours in \% of total hours, too warm uncomfortable hours in \% of total hours and too cold uncomfortable hours in \% of total hours are illustrated.

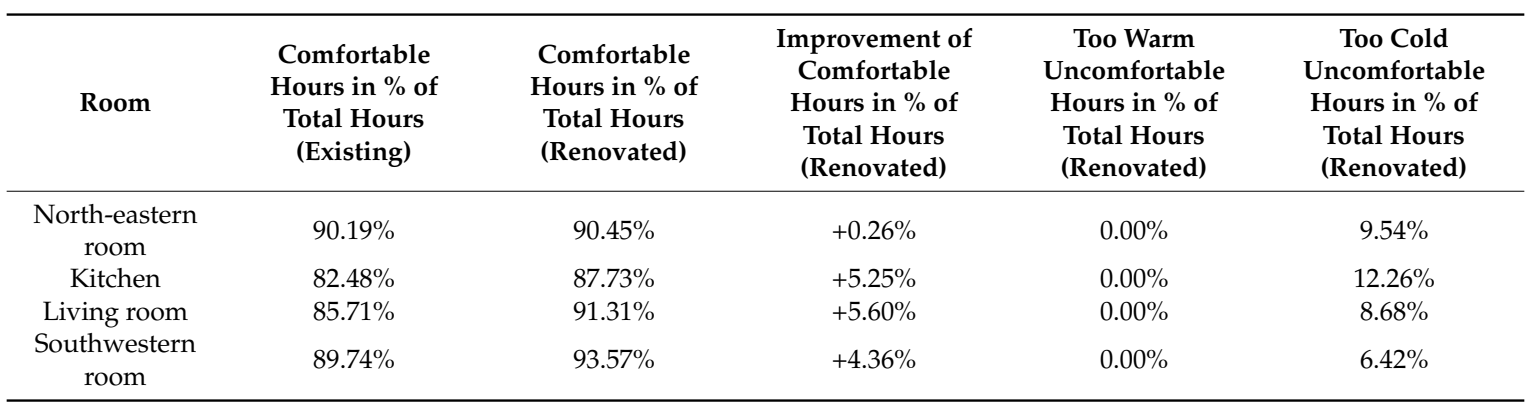

\subsection{BIM Model of Renovated Apartment Building 103}

The simulation of both comfort, heating and cooling energy demands defined the specific materials and dimensions of the improved building envelope components of the renovated apartment. The virtual geometries generated in Grasshopper have been exported to Revit and defined the base geometries for the definition of three component families with specific numbers of component types that were defined for the modular building envelope system of apartment building 103:

(i) 7 component types were developed for the north and south façade component category, both with and without windows. In the south façade, components with BIPV modules sound refraction elements were applied. In the north façade, panels made of recycled plastic were uses instead of BIPV modules. Panels of this category were also applied to the staircases of the three apartment core units and included access doors for the rooftop. The total number of applied components was 585 . 
(ii) 3 component types were developed for the roof components that were also equipped with BIPV panels. The total number of applied components was 211.

(iii) 6 component types were developed for the east and west façade and connection component category. The components were installed on the east and west facades of the building, as well as in the connecting areas. The concerned connections were between façades with different orientation, between the façades and the roof and between the basement wall extension and the first floor. The total number of applied components was 632 .

In total, 1428 modules were applied in the virtual model for the renovation of apartment building 103. The entire building volume was covered with the new building envelope system including the three vertical extensions of the central cores over the roof. All component connections were designed appropriately to avoid thermal bridges. Figure 15 illustrates the external south-south-west and north-north-west views of the refurbished apartment. Figure 16 illustrates the first (a) and the second (b) floor plan of the renovated apartment building 103.

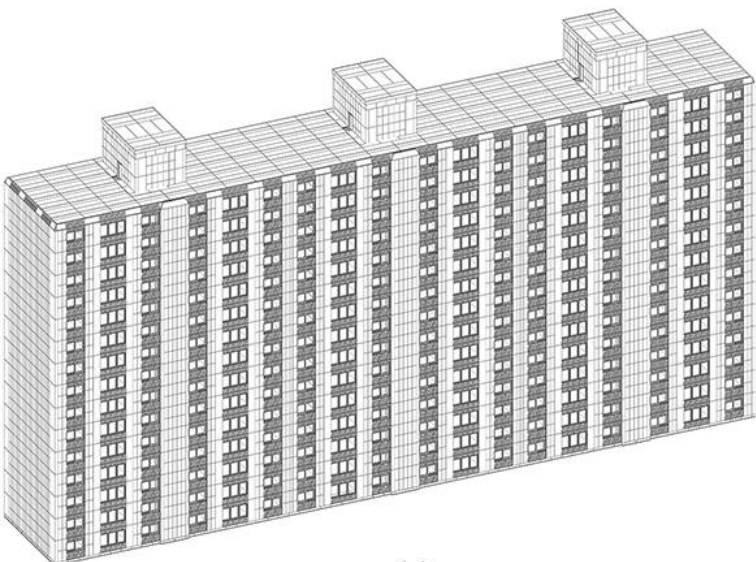

(a)

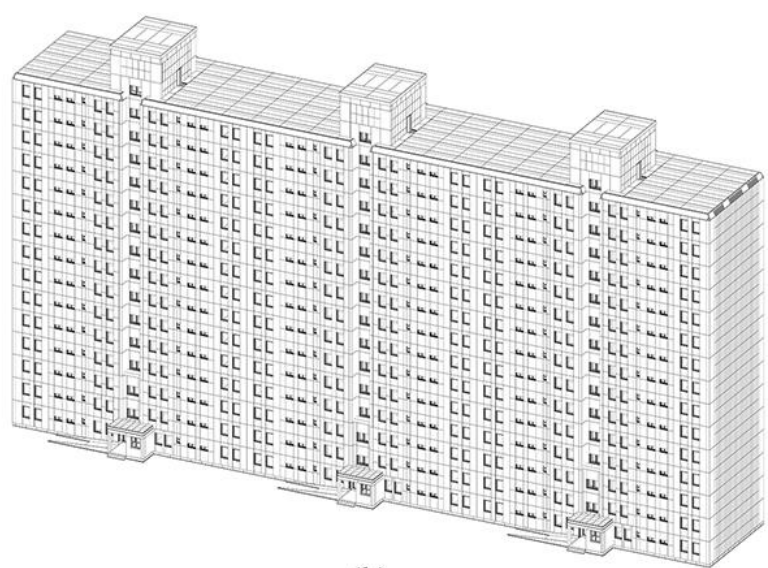

(b)

Figure 15. Isometric views of the refurbished apartment building 103 (a) from south-south-west and (b) from north-north-west.

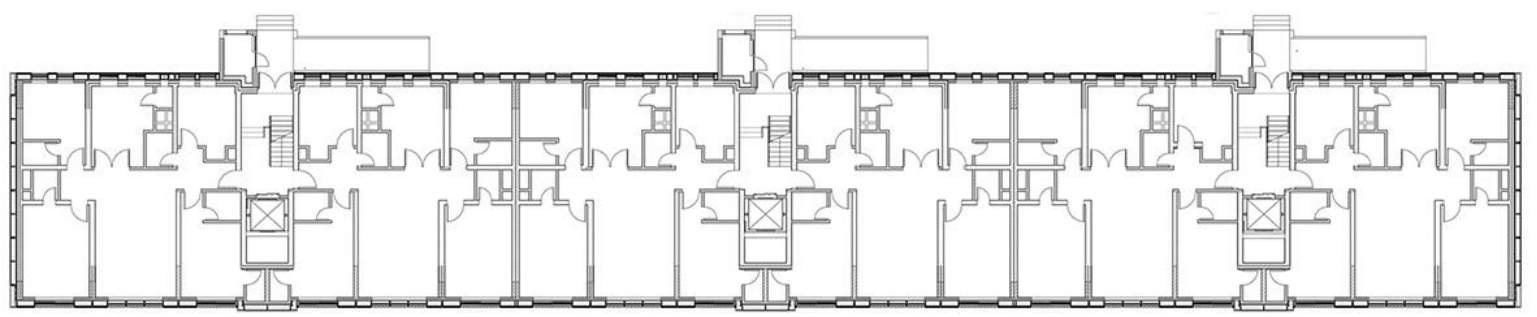

(a)

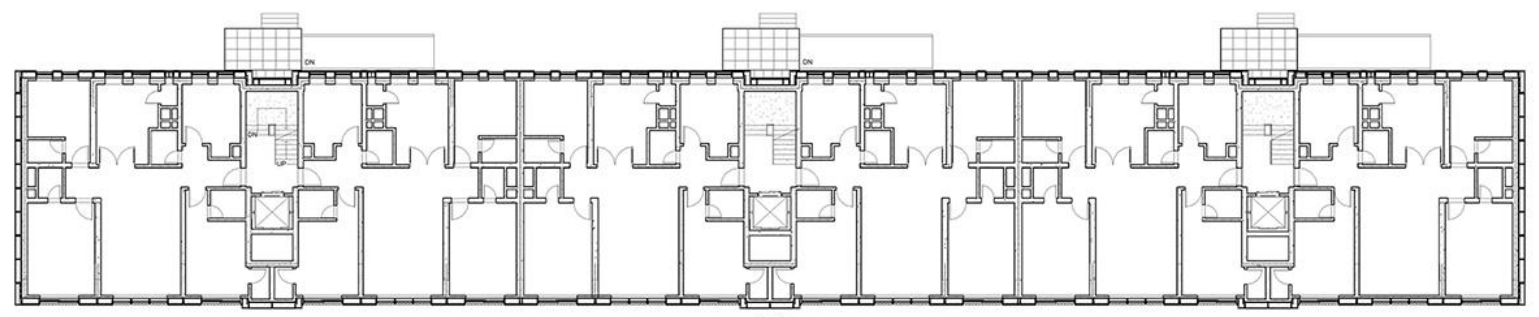

(b)

Figure 16. Reference first floor (a) and the second floor (b) plans of the renovated apartment building 103 with new building envelope and modified floor plan layouts.

Transmission heat losses between the main building with apartment units and staircases above the ground, the basement as well as with the three entrance areas on the ground floor of the north 
façade (Figure 15b) were reduced to the greatest possible degree. The ceiling of the basement floor and the interior and exterior wall surfaces of the basement floor walls were insulated with $20 \mathrm{~cm}$ mineral glass wool to a depth of $70 \mathrm{~cm}$ in order to reduce the thermal bridges caused by the connection between the ascending load bearing basement walls and the ground floor. The three entrance areas were also insulated from the outside with building envelope components.

\subsection{Photovoltaic Energy Production Simulation}

In the framework of apartment building's 103 renovation $44 \%$ of the total south façade and $57 \%$ of the total roof surface area was covered with PV-components with an efficiency of $16 \%$ [89]. Due to the comparable high percentage of $>30 \%$ of total annual shading hours it was decided to not install PV panels on the remaining facades. The total installed BIPV panel area was $2389.50 \mathrm{~m}^{2}$ and $26.55 \mathrm{~m}^{2}$, in average, per apartment unit. This area was divided in $14.55 \mathrm{~m}^{2} \mathrm{PV}$ façade and $12 \mathrm{~m}^{2}$ roof panels. The simulation of the photovoltaic energy production with Ladybug included efficiency reduction factors such as shading, soiling [90], snow covering [91], as well as conversion losses.

For the determination of the annual average PV production per apartment unit, the total number of apartment units had divided the total annual photovoltaic energy production. In the building simulation model the produced photovoltaic energy was balanced with the final energy demand for heating and cooling. Electric to thermal energy transformation losses were defined with $1 \%$ for hot water and electric boiler based floor heating as well as the air-to-air heat pump for cooling.

The ratio of the PV energy produced by the PV modules to the solar radiation received by the surfaces of the PV modules reached an annual average of $9 \%$ during 10 years of operation. Mainly soiling and shadowing caused the comparable low efficiency of the PV modules. The average annual reference apartment unit PV energy production was approximately $2233 \mathrm{kWh} / \mathrm{a}$. This amount of energy corresponds approximately with the annual cooling demand of the reference apartment unit. As a result, the annual PV energy production was similar to approximately $22 \%$ of the cumulative heating and cooling energy demand of the reference apartment unit.

\section{Discussion}

This research demonstrated the capabilities of an integrated BIM-parametric framework, for the definition of energy and comfort criteria and simulation of building performances according to defined criteria and specific basic conditions, for the renovation of aged apartment buildings in Korea. The building reconstruction and simulation of heating and cooling energy demands and comfort conditions required the utilization and combination of multiple software tools. Data and information that were required for the refurbishment of aged existing buildings were often difficult to access. Detailed building plans might have not been available and therefore an extensive analysis of an apartment building and the individual units was impossible. It was for this reason that this BIM-parametric framework was developed. This framework can be adapted and improved with updated data, without the need of manually change or reconstruction of the entire virtual building and the simulation models. Simulations and calculations of cooling and heating energy demands and comfort depend on the behaviour of residents and any other building users. Required data includes, occupation and ventilation schedules, as well as the specific preferences in comfort temperatures and set points.

The heating and cooling energy demands simulated in the framework of this research have been validated by a benchmark analysis of the heating energy demands of the existing reference apartment unit in building 103 with statistical data from 189 apartment buildings built between 1976 and the 2000 . The buildings were analysed in the framework of a research on the building simulation of Korean residential buildings [92,93]. The results provided the statistical data for the benchmark analysis of heating energy demand. Statistical data on the average annual heating energy consumption per square meter was selected from apartments built in 1992, the same year as building 103. The benchmark analysis illustrates that the heating energy demand calculated for the reference apartment unit is in the 
upper 30 percentile of the statistical distribution of heating energy consumption values for apartments built in 1992. The annual heating energy demand per square meter of the reference apartment unit is approximately $130 \mathrm{kWh} / \mathrm{m}^{2}$ a, which is $22.13 \mathrm{kWh} / \mathrm{m}^{2} \mathrm{a}(20 \%)$ higher than the average annual heating energy consumption per square meter calculated for the statistical apartment pool, of approximately $\left(108 \mathrm{kWh} / \mathrm{m}^{2} \mathrm{a}\right)$. The annual heating energy demand of the reference apartment unit lies in the standard deviation range between +1 and $+2 \sigma$ from the average heating energy consumption of the statistical apartment pool. Specific potential differences between the building of the statistical apartment pool and apartment building 103 include the average apartment unit gross floor areas; building envelope conditions (ventilation heat losses through the existing envelope) and operative schedules. Furthermore, the $20 \%$ difference between heating energy demand simulation results and average energy consumption can be explained by the program settings for the reference apartment unit simulation. The settings are based on the definition of comfort indoor target temperatures and humidity values primarily according to the adaptive comfort model. Statistical values of average comfort temperature set points in Korean apartments, for winter and summer, were corrected to fit in the comfortable temperature range of the adaptive model. However, it was observed that the residents and building users show different preferences in terms of indoor comfort temperatures, which may be different from the comfort temperature ranges defined in the adaptive model. Such differences result in differences in the simulated heating and cooling energy demand and the actual energy consumption. This research was based on modeling of theoretical occupants' behaviour with the aim to maximize indoor comfort. According to the stronger comfort requirements defined within this research, the energy demand simulation results exceeded the published statistical values. Notwithstanding the differences in terms of rationale and scope, heating demand results fall in the statistical range of differences between measured heating and cooling energy consumption data.

The final configuration and construction layer definition of the renovated envelope for apartment building 103 was based on the simulation of different building envelope optimization options. Results of different BIM-parametric simulation models were compared, a cyclic optimization of the building envelope was executed to optimize WWRs, U-values and PV module areas, and the modular building envelope renovation system was improved accordingly. An iterative procedure was established to identify and optimize specific parameters such as U-Values, materials, g-values and optical properties. Material and geometrical parameters defined with the parametric simulations where used to generate the improved building envelope components, to import them in the BIM program, and to define the modular families that were included in the virtual model of the renovated apartment building.

This research illustrated that the BIM-parametric and environmental analysis systems framework can be constantly and easily be updated and optimized. Updates, modifications and optimization can be executed with statistical data concerning building construction, building operation and information collected through direct surveys of existing buildings. Construction data of existing buildings can be used for the definition of improvement measures. In this research the improvement concerned, for example, the building envelope according to cyclic optimization processes of building construction variables for a modular building envelope component system.

To streamline the BIM-parametric framework and include additional analysis levels for the development of renovation strategies of aged apartment buildings, different improvements are under development, particularly the automation of optimization cycles and direct data transfer between BIM, CAD software and parametric environmental analysis tools [94]. In terms of building information management, the automated transfer of construction data from the BIM model to the parametric software can be executed by employing the Revit parametric suite Dynamo [95]. Dynamo facilitates the transmission of data such as the material layers of building components and their building physical properties, such as U-values, directly to Grasshopper.

Future research will include the Life-Cycle Assessment (LCA) and the structural simulation of the improved building envelope. LCA of single components building envelope systems will facilitate 
the quantification of environmental and economic cost of different renovation measures. LCA of complete buildings before and after renovation and in comparison with new constructions will also facilitate the comparison of environmental impacts and construction costs of different urban renewal measures. The structural analysis of apartment buildings before and after introduction of specific renovation measures is required to determine specific interventions and eventually necessary structural reinforcement measures. The future optimization process for the BIM-parametric framework aims for streamlining data transfer and improving the comparison of different building optimization strategies regarding sustainability criteria.

\section{Conclusions}

The discussed BIM-parametric workflow process and environmental analysis framework quantifies the effects of an exemplary aged apartment building renovation in the Republic of Korea regarding comfort criteria, heating and cooling energy demand and the building integrated production of photovoltaic energy. After renovation, the building's heating energy demand was reduced by $57 \%$ and the cooling energy demand was reduced by $11 \%$ compared to the existing building. Furthermore, the percentage of comfortable annual indoor hours was increased by $5 \%$. The improvements could be achieved by modification of the indoor room layout and installation of a modular and parametrically defined modular building envelope renovation system. The building envelope renovation system included the improvement of U-values, g-values, WWRs, air tightness and the installation of BIPV-panels. The results illustrate the improvement potential of existing apartment buildings by renovation of the building envelope, related with reduction of environmental impact, reduced annual energy demand and improved indoor comfort.

The modularity of the described building envelope renovation system facilitates the adaptability to projects with other apartment types. Furthermore, the renovation system could easily be prefabricated and on-site construction time could be reduced accordingly. The application of the BIM-parametric framework for an existing case-study building served as a good-practice example and aims to stimulate further research and development for the realization of sustainable building renovation initiatives in the Republic of Korea and beyond.

Author Contributions: The research was executed by F.M.A. with T.S. in South Korea and U.D. in Germany. All authors contributed equally to the writing of this paper and read and approved the final manuscript.

Funding: This research was supported by Basic Science Research Program through the National Research Foundation of Korea (NRF) and funded by the Ministry of Education (2018R1D1A1B07050989). This research was also supported by SungKyunKwan University 2018 College of Engineering Research Promotion Project.

Acknowledgments: The authors would like to thank Kyoyoung Hwang and Narae Lee for their assistance and translation of literature from Korean to English.

Conflicts of Interest: The authors declare no conflict of interest.

\section{References}

1. Statistics Korea (KOSTAT). Complete Enumeration Results of the 2016 Population and Housing Census; Statistics Korea (KOSTAT): Seoul, Korea, 2016.

2. Chung, I.-U. The Current Status of Old Apartments and the Remodeling Policies in Korea; Land \& Housing Corporation: Seoul, Korea, 2014.

3. Koh, C. Overview of Housing Policies \& Programs in Korea; Korea Housing Institute: Seoul, Korea, 2004.

4. Park, D.; Xiao, Q. Housing Prices and the Role of Speculation: The Case of Seoul; Asian Development Bank: Manila, Philippines, 2009.

5. Kim, S.-H. A Study on the Kumhwa District Apartment Life-Changes by Daily Newspaper in Korea. J. Archit. Inst. Korea Plan. Des. 2013, 29, 99-106.

6. Kim, S.A. Policy and Technology of Housing Remodeling in Korea; Korea Institute of Construction Technology: Ilsan, Korea, 2003. 
7. Ha, S.-K. Housing poverty and the role of urban governance in Korea. Environ. Urban. 2004, 16, $139-154$. [CrossRef]

8. Ha, S.K. Housing Policy and Practice in Korea; Croom Helm: London, UK, 1987.

9. Smith, N. Gentrification and the rent gap. Ann. Assoc. Am. Geogr. 1987, 77, 462-465. [CrossRef]

10. Shin, H.B. Property-based redevelopment and gentrification: The case of Seoul, South Korea. Geoforum 2009, 40, 906-917. [CrossRef]

11. Ha, S.-K. New shantytowns and the urban marginalized in Seoul Metropolitan Region. Habitat Int. 2004, 28, 123-141. [CrossRef]

12. Lee, J.Y. The Practice of Urban Renewal in Seoul, Korea: Mode, Governance, and Sustainability. In Proceedings of the 2nd International Critical Geography Conference, Taegu, Korea, 9-13 August 2000; p. 22.

13. Kim, J.; Meulder, B.D. Speculative self-destruction, gateways for hyper-redevelopment in Seoul, South Korea. In Trends and Issues in Housing in Asia: Coming of an Age; Sengupta, U., Shaw, A., Eds.; Taylor \& Francis: Abingdon, UK, 2017.

14. Kang, H.L.; Chang, U.C.; Park, G.S. A Study on the Maintenance Cost Elasticity of the Apartment Housing. J. Korean Hous. Assoc. 2011, 22, 51-60.

15. Bang Shin, H. Living on the edge: Financing post-displacement housing in urban redevelopment projects in Seoul. Environ. Urban. 2008, 20, 411-426. [CrossRef]

16. Lee, S. Urban Housing Policy in Korea according to Paradigm Shift; Korea Research Institute for Human Settlements: Seoul, Korea, 2016.

17. Kim, K. Housing Redevelopment and Neighborhood Change as A Gentrification Process in Seoul, Korea: A Case Study of the Wolgok-4 Dong Redevelopment District; Florida State University: Tallahassee, FL, USA, 2006.

18. Kyoung, S.; Kim, K.-J. State-Facilitated Gentrification'in Seoul, South Korea for Whom, by Whom and with What Result; Research Committee 21: Amsterdam, The Netherlands, 2011.

19. Lee, M.-K.; Kim, Y.-S.; Kang, S.-J.; Ryu, J.-C.; Kim, W.-D.; Han, K.-J.; Balmes, C.; Lee, Y.-H.; Kim, S.-J. Korea's Green Growth Experience: Process, Outcomes and Lessons Learned; Global Green Growth Instittue: Seoul, Korea, 2015.

20. Jänicke, M. “Green growth": From a growing eco-industry to economic sustainability. Energy Policy 2012, 48, 13-21. [CrossRef]

21. Jones, R.S.; Yoo, B. Achieving the "Low Carbon, Green Growth" Vision in Korea; OECD: Paris, France, 2012.

22. Jacobs, M. The Green Economy; Pluto Press: London, UK, 1991.

23. Olivier, J.; Jannsens-Maenhout, G.; Peters, J. Trends in Global $\mathrm{CO}_{2}$ Emissions; Publications Office: Luxembourg, 2012.

24. Jeong, H. Sustainability Policy and Green Growth of the South Korean Construction Industry. Master' Thesis, Texas A \& M University, College Station, TX, USA, 2011.

25. Schuetze, T. Zero Emission Buildings in Korea-History, Status Quo, and Future Prospects. Sustainability 2015, 7, 2745-2767. [CrossRef]

26. Kang, H. Korean Green Building Code. Samsung Econ. Res. Inst. Q. 2010, 3, 7.

27. Yoon, Y.S. Zero Energy Buildings in Korea-Korea Energy Policies for Sustainable Building. In Zero Energy Building Workshop 2012; Fraunhofer Representative Office Korea, Energy Dream Center: Seoul, Korea, 2012; Volume 1.

28. Schuetze, T.; Chelleri, L. Urban Sustainability Versus Green-Washing-Fallacy and Reality of Urban Regeneration in Downtown Seoul. Sustainability 2016, 8, 33. [CrossRef]

29. Park, M.; Tae, S. Suggestions of Policy Direction to Improve the Housing Quality in South Korea. Sustainability 2016, 8, 438. [CrossRef]

30. Ko, Y.; Schubert, D.K.; Hester, R.T. A Conflict of Greens: Green Development versus Habitat Preservation-The Case of Incheon, South Korea. Environ. Sci. Policy Sustain. Dev. 2011, 53, 3-17. [CrossRef]

31. Ko, Y.; Schubert, D.K. “Green” New Deal Projects Threaten Korea's Rivers and Tidal Flats. In International Rivers-People-Water-Life; International Rivers: Oakland, CA, USA, 2011.

32. Lee, B.S.; Chung, E.-C.; Kim, Y.H. Dwelling Age, Redevelopment, and Housing Prices: The Case of Apartment Complexes in Seoul. J. Real Estate Financ. Econ. 2005, 30, 55-80. [CrossRef]

33. Cha, H.S.; Kim, K.H.; Kim, C.K. Case Study on Selective Demolition Method for Refurbishing Deteriorated Residential Apartments. J. Constr. Eng. Manag. 2012, 138, 294-303. [CrossRef] 
34. Jeong, Y.-S.; Lee, S.-E.; Huh, J.-H. Estimation of $\mathrm{CO}_{2}$ emission of apartment buildings due to major construction materials in the Republic of Korea. Energy Build. 2012, 49, 437-442. [CrossRef]

35. Shin, H.B.; Kim, S.-H. The developmental state, speculative urbanisation and the politics of displacement in gentrifying Seoul. Urban Stud. 2015, 53, 540-559. [CrossRef]

36. Kim, J.-H.; Kim, H.-J.; Yoo, S.-H. Consumers' Willingness to Pay for Net-Zero Energy Apartment in South Korea. Sustainability 2018, 10, 1564. [CrossRef]

37. Park, W.-J.; Kim, H.-M. Study on the Improvement of Expected Energy Savings and Actual Energy Savings in Apartments. Sustainability 2018, 10, 1089. [CrossRef]

38. Bucoń, R.; Tomczak, M. Decision-making model supporting the process of planning expenditures for residential building renovation. Technol. Econ. Dev. Econ. 2018, 24, 1200-1214. [CrossRef]

39. Hyun Hong, J.; Jun Yeom, D.; Ji Choi, S.; Suk Kim, Y. A Study of the Decision Support Model to Select an Appropriate Alternative Plan in Apartment Remodeling. J. Archit. Inst. Korea Struct. Constr. 2017, 33, 41-50. [CrossRef]

40. Shin, H.-I. A Study on the Energy Consumption and their Patterns in Apartment Housing Units Size and Orientation. J. Archit. Inst. Korea Plan. Des. 2016, 32, 231-240. [CrossRef]

41. Choi, I.Y.; Cho, S.H.; Kim, J.T. Energy consumption characteristics of high-rise apartment buildings according to building shape and mixed-use development. Energy Build. 2012, 46, 123-131. [CrossRef]

42. Kim, Y.-I.; Song, S.-Y. Energy Consumption status of Apartment Buildings and Influence of Various Factors on Energy Consumption. J. Korean Sol. Energy Soc. 2014, 34, 93-102. [CrossRef]

43. Jeong, Y.-S.; Jung, H.-K.; Yu, K.-H. Energy Consumption Assessment of Reference Apartment House Using Simulation. J. Archit. Inst. Korea 2014, 34, 407-408.

44. Lee, W.-J.; Kang, E.-C.; Lee, E.-J.; Oh, B.-C.; Shin, U.-C. Case Study on the Energy Consumption Unit of District Apartments. Korean J. Air-Cond. Refrig. Eng. 2014, 26, 474-480.

45. Yeo, M.-S.; Yang, I.-H.; Kim, K.-W. Historical changes and recent energy saving potential of residential heating in Korea. Energy Build. 2003, 35, 715-727. [CrossRef]

46. Kim, S.; Lee, D.; Hong, H. An Energy Saving Technique Using Ondol Heating Schedule Control of Housing Units in Korea. Indoor Built Environ. 2010, 19, 88-93. [CrossRef]

47. Park, S.-H.; Lee, S.-H.; Park, J.-C.; Rhee, E.-K.; Cho, K.-H. A Survey on Energy Consumption through Operational Level in Apartment Buildings. J. Archit. Inst. Korea Plan. Des. 2014, 30, 233-240. [CrossRef]

48. Cho, S.-H.; Kang, J.-S.K.; Choi, G.-S. Energy Performance Evaluation of External Insulation System for Post Remodeling in Apartment Buildings. In Proceedings of the SAREK 2016 Summer Annual Conference, Seoul, Korea, 5-7 July 2016; pp. 176-178.

49. Kim, D.S.; Yoon, J.H.; Shin, C.U.; Kwak, H.Y. A study on the annual energy performance of apartment building with the equivalent $U$-value of envelope considering the effect of thermal bridges. KIEAE J. 2012, $12,41-46$.

50. Kim, S.-H.; Lee, J.-G.; Kim, Y.-T.; Lee, K.-H. Energy Load according to the Units of Apartment House. J. Korean Soc. Power Syst. Eng. 2015, 19, 78-83. [CrossRef]

51. Hye-Soo, S.; Byung-Seo, K. A Comparative Analysis of Energy Simulation Results and Actual Energy Consumption on Super High-rise Apartments. J. Korean Sol. Energy Soc. 2011, 31, 34-40.

52. Kim, J.; Ryu, J.; Choo, S. An Analysis on Effectiveness of BIM-based Area Calculation Method for Improving Quality of Korean Apartment Housing. J. Korean Hous. Assoc. 2013, 24, 45-52.

53. Kim, H.; Lee, J.K. BIM-Enabled Evaluation of Design Alternatives in Design Phase for Remodeling Project-Based on an Actual Apartment Case in Yeongwol. Available online: http://www.dbpia.co.kr/ Article/NODE06554747 (accessed on 20 November 2018).

54. Khemlani, L. Autodesk Revit: Implementation in Practice; White Paper; Autodesk: San Rafael, CA, USA, 2004.

55. McNeel, R. Grasshopper Generative Modeling for Rhino. Computer Software (2011b). Available online: http:/ / www.grasshopper3d.com (accessed on 20 November 2018).

56. Fylstra, D.; Lasdon, L.; Watson, J.; Waren, A. Design and Use of the Microsoft Excel Solver. Interfaces 1998, 28, 29-55. [CrossRef]

57. Mans, D.B. Bumblebee. Available online: https://www.grasshopper3d.com/group/bumblebee (accessed on 21 September 2018). 
58. Roudsari, M.S.; Pak, M. Ladybug: A parametric environmental plugin for grasshopper to help designers create an environmentally conscious design. In Proceedings of the 13th International IBPSA Conference, Lyon, France, 25-30 August 2013.

59. LBNL. LBNL, WINDOW 7beta: PC Program for Analyzing Window Thermal Per-Formance; LBNL: Berkeley, CA, USA, 2012.

60. Finlayson, E.; Mitchell, R.; Arasteh, D.; Huizenga, C.; Curcija, D. THERM 2.0: Program Description. A PC Program for Analyzing the Two-Dimensional Heat Transfer through Building Products; LBL-37371 Rev.; Lawrence Berkeley National Laboratory: Berkeley, CA, USA, 1998.

61. Larson, G.W.; Shakespeare, R. Rendering With Radiance: The Art and Science of Lighting Visualization; Booksurge LLC: Charleston, SC, USA, 2004.

62. Crawley, D.B.; Lawrie, L.K.; Winkelmann, F.C.; Buhl, W.F.; Huang, Y.J.; Pedersen, C.O.; Strand, R.K.; Liesen, R.J.; Fisher, D.E.; Witte, M.J.; et al. EnergyPlus: Creating a new-generation building energy simulation program. Energy Build. 2001, 33, 319-331. [CrossRef]

63. De Dear, R. Recent enhancements to the adaptive comfort standard in ASHRAE 55-2010. In Proceedings of the 45th Annual Conference of the Architectural Science Association, Sydney, Australia, 16-19 November 2011.

64. CEN. EN 15251-Indoor Environmental Input Parameters for Design and Assessment of Energy Performance of Buildingsaddressing Indoor Air Quality, Thermal Environment, Lighting and Acoustics; CEN: Brussels, Belgium, 2007.

65. Deuble, M.P.; de Dear, R.J. Mixed-mode buildings: A double standard in occupants' comfort expectations. Build. Environ. 2012, 54, 53-60. [CrossRef]

66. Van der Linden, A.C.; Boerstra, A.C.; Raue, A.K.; Kurvers, S.R.; de Dear, R.J. Adaptive temperature limits: A new guideline in The Netherlands: A new approach for the assessment of building performance with respect to thermal indoor climate. Energy Build. 2006, 38, 8-17. [CrossRef]

67. Han, S.; Lee, G. A Quantitative Analysis of the Apartment Unit types in South Korea. J. Hous. Sci. 2010, $34,8$.

68. VV., A. Apartment Encyclopedia (Seoul and Bundang/Ilsan); Seijn Planning: Seoul, Korea, 1998; Volume 2, p. 259.

69. Park, B.-I.; Seok, H.-T.; Kim, K.-W. The historical changes of ONDOL. Mag. Soc. Air-Cond. Refrig. Eng. Korea 1995, 24, 613-627.

70. Jeon, N. Spatial History of Housing in South Korea (Hangukjugeogonggansa); Dolbaegae: Paju, Korea, 2008.

71. Tae, S.; Shin, S. Current work and future trends for sustainable buildings in South Korea. Renew. Sustain. Energy Rev. 2009, 13, 1910-1921. [CrossRef]

72. Il, I.K. A comparative Study on Apartment Unit Plans of SH Corporation and Private Construction Company in the Housing Development District; Seoul City University: Seoul, Korea, 2013.

73. Schuetze, T. Passive Houses in Korea; Sungkyunkwan University: Seoul, Korea, 2017.

74. Kim, J.; Chun, J.; Lee, B. Study about Change of Insulation Standard in Apartment in Its Effect. J. Archit. Inst. Korea 2009, 11, 125-132.

75. Yoon, S.; Jang, H.; Kim, Y. Analysis on the Characteristics of Thermal Load classified by the Household Location in Apartment House. J. Archit. Inst. Korea Plan. Des. 2009, 25, $289-296$.

76. ASHRAE. ANSI/ASHRAE Standard 62.1-2010. Ventilation for Acceptable Indoor Air Quality; American Society of Heating, Refrigerating, and Air-Conditioning Engineers, Inc.: Altanta, GA, USA, 2010.

77. Maddalena, R.; Mendell, M.J.; Eliseeva, K.; Chan, W.R.; Sullivan, D.P.; Russell, M.; Satish, U.; Fisk, W.J. Effects of ventilation rate per person and per floor area on perceived air quality, sick building syndrome symptoms, and decision-making. Indoor Air 2015, 25, 362-370. [CrossRef] [PubMed]

78. O'Neill, Z.; Narayanan, S.; Brahme, R. Model-based thermal load estimation in buildings. In Proceedings of the Fourth National Conference of IBPSA-US, New York, NY, USA, 11-13 August 2010.

79. Choi, Y.J.; Shim, H.S.; Jeong, Y.H. Elements and Actual Condition of Apartment Unit Remodeling-By In-depth Interviews on Residents and Specialists of Interior Design Companies. J. Korean Hous. Assoc. 2007, 18, 57-67.

80. Seo, B.K.; Choi, J.O. A Study on Tendency of Extended Balcony Unit Plans of LH Corp. J. Korean Inst. Inter. Des. 2011, 20, 146-153.

81. Seong, B.M.; Kim, W.P. A Study on Residential Satisfaction with Diversion of Expanded Balcony Area at Multi-family Housing through Residents' Survey. J. Archit. Inst. Korea Plan. Des. 2011, 27, 317-324.

82. Park, C.-S. Emerging from Customary Design for Balcony Space in Apartment. J. Archit. Inst. Korea Plan. Des. 2004, 20, 67-76.

83. VV., A. The Current Situation of Improved Regulation and Remodeling System; MOLIT-Housing Redevelopment Division: Seoul, Korea, 2014. 
84. Breheny, M. Superglass Cavity Wall Insulation BRA Technical Approval Certificate; Superglass Insulation Ltd.: Stirling, UK, 2017.

85. Smile Plastics. Available online: https:// smile-plastics.com/ (accessed on 23 July 2018).

86. Wecobis.de. Available online: https://www.wecobis.de/ (accessed on 15 July 2018).

87. Oekobaudat.de. Available online: https://www.oekobaudat.de/ (accessed on 20 July 2018).

88. DGNB. DNGB Kriterienuebersicht-Sanierung Büro- und Verwaltungsgebäude, Version 2016; DGNB: Stuttgart, Germany, 2016.

89. Green, M.A.; Emery, K.; Hishikawa, Y.; Warta, W. Solar cell efficiency tables (version 37). Prog. Photovolt. Res. Appl. 2011, 19, 84-92. [CrossRef]

90. Mejia, F.; Kleissl, J.; Bosch, J.L. The Effect of Dust on Solar Photovoltaic Systems. Energy Procedia 2014, 49, 2370-2376. [CrossRef]

91. Seoul Monthly Climate Averages. Available online: https://www.worldweatheronline.com/seoul-weatheraverages/kr.aspx (accessed on 20 August 2018).

92. Jang, H. Modelling of Existing High-Rise Apartment Buildings for Energy-Efficient Refurbishment in South Korea. Ph.D. Thesis, University of Sheffield, Sheffield, UK, 2016.

93. Jang, H.; Jones, L.; Kang, J. Prioritisation of old apartment buildings for energy-efficient refurbishment based on the effects of building features on energy consumption in South Korea. Energy Build. 2015, 96, 319-328. [CrossRef]

94. Sanyal, J.; New, J. Simulation and big data challenges in tuning building energy models. In Proceedings of the 2013 Workshop on Modeling and Simulation of Cyber-Physical Energy Systems (MSCPES), Berkeley, CA, USA, 20-23 May 2013; pp. 1-6.

95. Keough, I. Dynamo: Designing a Visual Scripting Interface for the Revit API (Notes). More Inf. about Coding Dynamo 2011. Available online: https:/ / github.com/ikeough/Dynamo/wiki (accessed on 26 August 2018).

(C) 2018 by the authors. Licensee MDPI, Basel, Switzerland. This article is an open access article distributed under the terms and conditions of the Creative Commons Attribution (CC BY) license (http:/ / creativecommons.org/licenses/by/4.0/). 